\title{
Metformin exerts antitumor activity via induction of multiple death pathways in tumor cells and activation of a protective immune response
}

\author{
Felipe V. Pereira ${ }^{1,4}$, Amanda Campelo L. Melo ${ }^{1}$, Jun Siong Low ${ }^{4}$, Íris Arantes de \\ Castro ${ }^{1}$, Tárcio T. Braga ${ }^{1}$, Danilo C. Almeida ${ }^{1}$, Ana Gabriela U. Batista de Lima ${ }^{2}$, \\ Meire I. Hiyane ${ }^{1}$, Matheus Correa-Costa ${ }^{1}$, Vinicius Andrade-Oliveira ${ }^{1}$, Clarice S.T. \\ Origassa ${ }^{1}$, Rosana M. Pereira ${ }^{3}$, Susan M. Kaech ${ }^{4}$, Elaine G. Rodrigues ${ }^{2}$ and Niels \\ Olsen S. Câmara ${ }^{1}$ \\ ${ }^{1}$ Laboratory of Transplantation Immunobiology, Department of Immunology, University of São Paulo, Institute of Biomedical \\ Sciences, 05508-900 São Paulo, SP, Brazil \\ ${ }^{2}$ Laboratory of Cancer Immunobiology, Department of Microbiology, Immunology and Parasitology, Escola Paulista de \\ Medicina, Universidade Federal de São Paulo (EPM-UNIFESP), 04023-062 São Paulo, SP, Brazil \\ ${ }^{3}$ Laboratory of Infectious Diseases, Department of Immunology, Institute of Biomedical Sciences, University of São Paulo, \\ 05508-900 São Paulo, SP, Brazil \\ ${ }^{4}$ Department of Immunobiology, Yale University School of Medicine, 06520 New Haven, CT, USA \\ Correspondence to: Felipe V. Pereira, email: felipevalencap@yahoo.com.br \\ Keywords: metformin; tumor immunity; T cells; cell death; sitagliptin \\ Received: March 19, $2016 \quad$ Accepted: April 24, $2018 \quad$ Published: May 25, 2018 \\ Copyright: Pereira et al. This is an open-access article distributed under the terms of the Creative Commons Attribution License \\ 3.0 (CC BY 3.0), which permits unrestricted use, distribution, and reproduction in any medium, provided the original author and \\ source are credited.
}

\section{ABSTRACT}

The antitumor effect of metformin has been demonstrated in several types of cancer; however, the mechanisms involved are incompletely understood. In this study, we showed that metformin acts directly on melanoma cells as well as on the tumor microenvironment, particularly in the context of the immune response. In vitro, metformin induces a complex interplay between apoptosis and autophagy in melanoma cells. The anti-metastatic activity of metformin in vivo was assessed in several mouse models challenged with B16F10 cells. Metformin's activity was, in part, immune system-dependent, whereas its antitumor properties were abrogated in immunodeficient (NSG) mice. Metformin treatment increased the number of lung CD8-effector-memory $\mathrm{T}$ and $\mathrm{CD}^{+}{ }^{+} \mathrm{Foxp}^{+} \mathrm{IL}^{-10^{+}} \mathrm{T}$ cells in B16F10-transplanted mice. It also decreased the levels of $\mathrm{Gr}^{-1}{ }^{+} \mathrm{CD} 11 \mathrm{~b}^{+}$and $\mathrm{RORY}^{+} \mathrm{IL17}^{+} \mathrm{CD} 4^{+}$cells in B16F10-injected mice and the anti-metastatic effect was impaired in RAG-1/mice challenged with B16F10 cells, suggesting an important role for $T$ cells in the protection induced by metformin. Finally, metformin in combination with the clinical metabolic agents rapamycin and sitagliptin showed a higher antitumor effect. The metformin/sitagliptin combination was effective in a BRAFV600E/PTEN tamoxifeninducible murine melanoma model. Taken together, these results suggest that metformin has a pronounced effect on melanoma cells, including the induction of a strong protective immune response in the tumor microenvironment, leading to tumor growth control, and the combination with other metabolic agents may increase this effect. 


\section{INTRODUCTION}

Melanoma is the most aggressive form of dermal/ skin cancer. Its development is associated with both genetic predisposition and exposure to environmental factors [1]. Although great advances have been achieved in melanoma treatment, including the recent introduction of targeted therapies such as vemurafenib, a BRAF inhibitor, and ipilimumab, an anti-CTLA-4 agent, new drugs and therapeutic strategies are urgently needed $[2,3]$.

Metformin is one of the most commonly prescribed drugs for the treatment of type 2 diabetes (T2D). Its anti-diabetic effect is attributed to inhibition of hepatic gluconeogenesis, which is possibly associated with insulin-mediated increase in glucose uptake in skeletal muscle [4]. Recently, epidemiological data and experimental studies have shown the antitumor effect of metformin against several types of cancer, including melanoma [5, 6]. Metformin can reduce levels of Ki-67, a marker of proliferation, in biopsy samples of non-diabetic women with breast cancer [7]. However, the mechanisms by which metformin acts to attenuate tumor progression are not well-defined, and relevant information is limited. Assessing the in vitro anti-proliferative properties of metformin in patients is challenging, especially when it is effective only at supra-physiological concentrations in vivo [8]. The systemic effects of metformin on tumorigenesis are associated with decreased hyperinsulinemia, which in turn is associated with poor prognosis in several types of cancer, including breast, colon, and prostate [9]. Additional studies have shown that metformin can influence cancer cells directly, mainly via AMP-activated kinase (AMPK)dependent and independent mechanisms [10].

Moreover, it has been reported that metformin can affect the immune system in healthy patients and in disorders such as autoimmune disease, tuberculosis, and cancer [11-14]. Some studies have also demonstrated that metformin affects $\mathrm{T}$ effector cell subsets and promotes the generation of memory T cells via the AMPK pathway [1517]. However, it has also been suggested that metformin can regulate cell growth and $\mathrm{T}$ cell proliferation via mechanisms that are not dependent on AMPK expression [18]. Metformin affects lymphocytes, macrophages, neutrophils, and other immune cells, and can modulate the secretion of a number of cytokines, such as interleukin (IL)-10, IL-17, IFN- $\gamma$, IL-22, and IL-6 [14, 19-21].

In this study, we tested the hypothesis that metformin could act bidirectionally on melanoma cells as well as on effector protective immune cells, contributing to tumor control. We evaluated multiple mechanisms of cell death in melanoma cells, including apoptosis, autophagy, caspase-independent pathways, and the participation of the receptor-interacting serine/threonine-protein kinase 1 (RIPK1) cascade. We tested the anti-metastatic effect of metformin in a set of B16F10-challenged mouse models to evaluate the role of the immune system in metformin's protective action. The combined effects of metformin with rapamycin and sitagliptin were also evaluated. Collectively, these findings indicate that the anticancer actions of metformin are multi-faceted.

\section{RESULTS}

\section{Metformin affects melanoma cells and migration}

To evaluate the direct effect of metformin on melanoma cells, we performed in vitro viability assays where dose- and time-dependent effects on B16F10 murine melanoma cells were observed. Treatment with different concentrations of metformin for 24,48 , and $72 \mathrm{~h}$ reduced B16F10 cell viability (Figure 1A). Interestingly, human melanoma cells isolated from patients were also sensitive to metformin. MEL25, MEL28, and MEL11 human cell lines were treated for $72 \mathrm{~h}$ with different concentrations of metformin $(0-40 \mathrm{mM})$, and cell viability was assessed by the MTT assay (Figure 1B). MEL25 was the most metformin-sensitive cell line, whereas MEL28 cells exhibited marked resistance to treatment, and MEL11 showed intermediate sensitivity (Figure 1B). In all three cases analyzed, the effect of metformin treatment was dose-dependent.

The ability of metformin to modulate cell migration was tested using a monolayer wound-healing assay. MEL11 human melanoma cells were incubated with metformin, at a concentration $(5 \mathrm{mM})$ that did not induce cell death, for $24 \mathrm{~h}$. This treatment inhibited cell migration compared to that of control cells (Figure 1C; Supplementary Figure 1). Metformin had no effect on the migration of MEL25 and MEL28 cell lines (data not shown).

Several studies have reported that metformin acts on mitochondria through inhibition of the respiratory complex I and alteration of energy production by tumor cells [22$23]$. We therefore measured the oxygen consumption rate (OCR) of B16F10 cells after treatment with metformin. We observed that metformin treatment reduced OCR in treated cells compared with that in untreated cells (Figure 1D).

This dose-dependent effect of metformin on cell viability was also evident in the assay for the determination of lactate dehydrogenase (LDH) release; treatment for only $24 \mathrm{~h}$ with 20 and $40 \mathrm{mM}$ metformin markedly increased LDH release in the culture media (Figure 1E).

\section{Metformin induces different mechanisms of cell death in melanoma cells}

To gain more insight into the pathways by which metformin impairs cell viability, we performed a focused gene pathway assay comprising the gene expression profile of key molecules associated with central mechanisms 
of cell death (i.e. apoptosis, autophagy, and necrosis). Genes that showed at least a two-fold difference in expression between metformin-treated cells (10 mM, 24 h) and controls (RPMI media only) were plotted (Figure 2A). Metformin treatment greatly increased the mRNA expression of Ctsb and Bax, whereas levels of IgfI, Ifng, Fasl, and Sycp 2 transcripts markedly decreased (Figure 2A, bar graph). Overall, metformin modulated the genes associated with various death processes as follows: autophagy (13 genes), pro-apoptosis (16 genes), necrosis (19 genes), and anti-apoptosis (4 genes) (Figure 2A, pie chart). We also found an increase in B16F10 apoptosis using Annexin V/7-AAD labeling after treatment with metformin (Figure 2B). Metformin treatment decreased the gene expression of Hif- $1 \alpha$ and Socs-3, genes associated with cancer cell resistance to death [24, 25], in B16F10 cells (Figure 2C); these genes have been reported as targets of metformin in different tumor types $[25,26]$. Conversely,
A

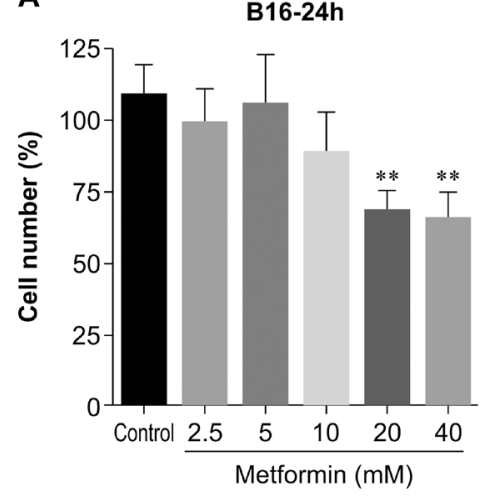

B

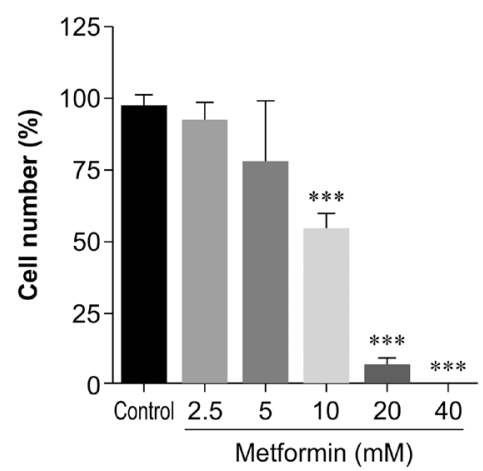

C

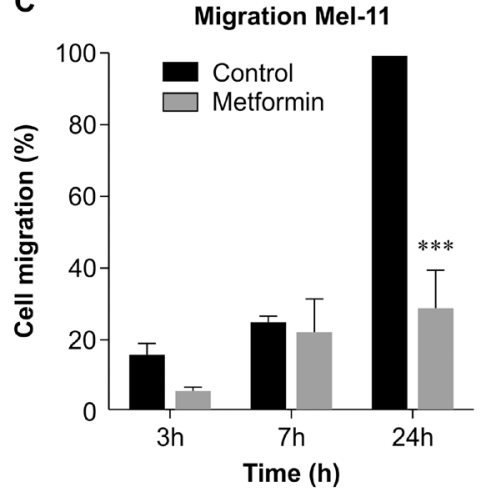

B16-48h

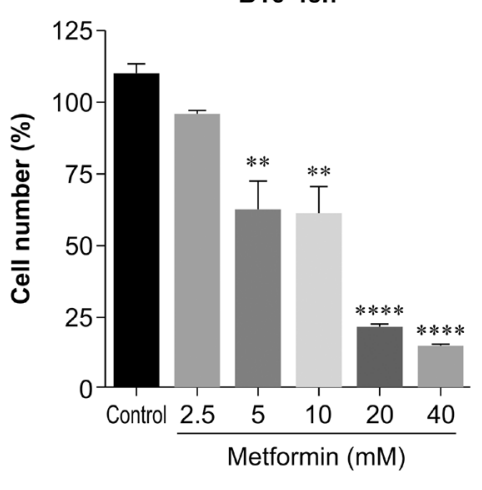

72h-MEL-28

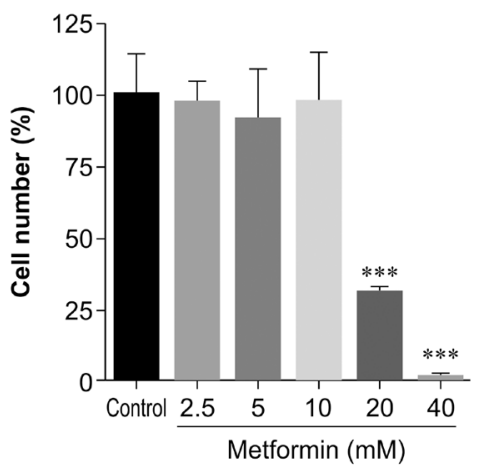

D

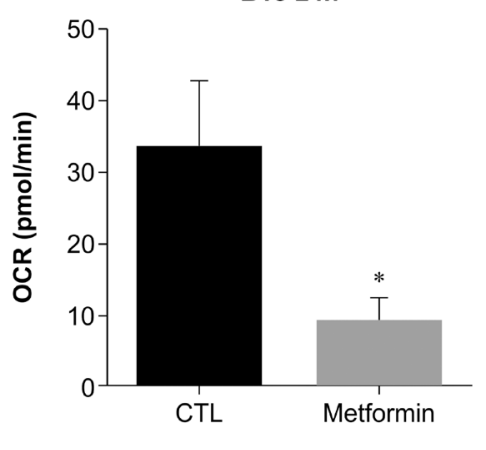

B16-72h

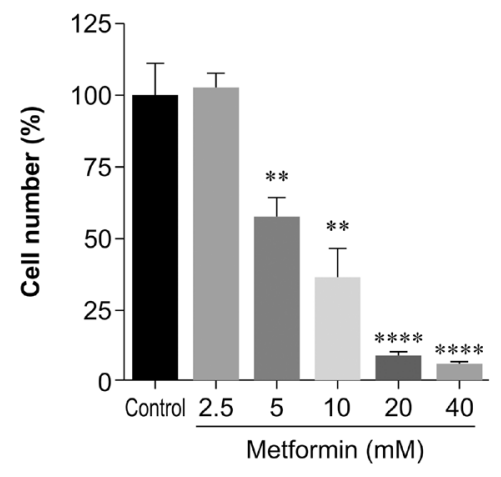

72h-MEL-11

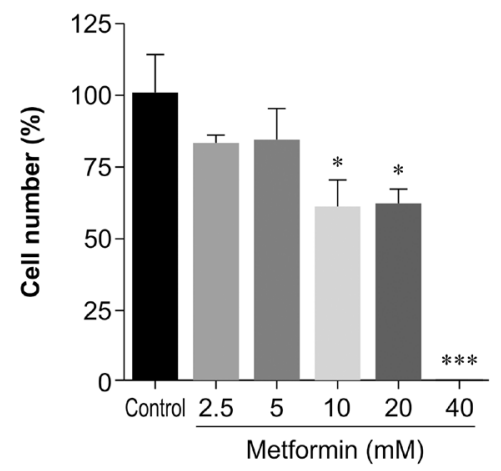

E

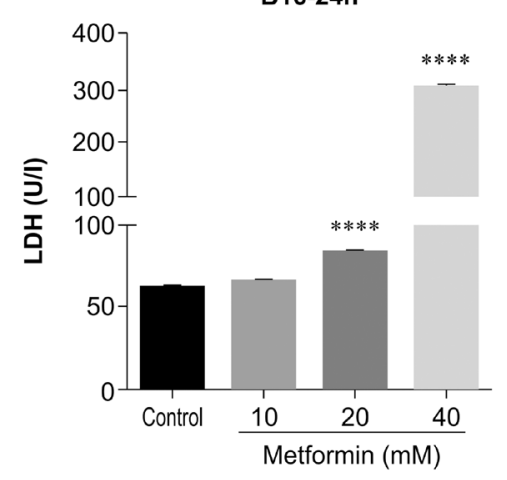

Figure 1: Metformin effects in melanoma cells in vitro. (A) B16F10 cells $\left(5 \times 10^{3}\right)$ were incubated for 24 , 48 , or $72 \mathrm{~h}$ with metformin $(0-40 \mathrm{mM})$, and cell viability was measured using the MTT assay $\left(^{* *} p<0.002,{ }^{* * * *} p<0.0001\right)$. (B) Different patient melanoma cells (Mel25, Mel28, and Mel11) were incubated with metformin ( $0-40 \mathrm{mM}$ ) for $72 \mathrm{~h}$, and cell viability was measured using the MTT assay $\left({ }^{* * *} p<0.003\right)$. (C) Patient Mel11 cell migration was determined by measuring wound width at 0,3 , and $7 \mathrm{~h}$, and $24 \mathrm{~h}$ after incubation with $5 \mathrm{mM}$ of metformin $\left({ }^{* * *} p<0.003\right)$. (D) Oxygen consumption rate of B16F10 cells treated with metformin $(10 \mathrm{mM})$ for $18 \mathrm{~h}\left({ }^{*} p<0.05\right)$. (E) B16F10 cells were incubated for $24 \mathrm{~h}$ with metformin $(0-40 \mathrm{mM})$, and lactate dehydrogenase (LDH) levels were measured in the supernatant after a $24-\mathrm{h}$ incubation $\left({ }^{* * * *} p<0.0001\right)$. 
the expression of Beclin1, an autophagy-related gene, increased after metformin treatment (Figure 2C).

The expression of Casp1, Casp6, and Casp7 was reduced by metformin treatment, as demonstrated by the PCR array assay (Figure 1A, bar chart). To assess whether caspases are directly involved in the cell death process mediated by metformin, we treated B16F10 cells with metformin $(20 \mathrm{mM})$ for $24 \mathrm{~h}$ in the presence of either a pan-caspase inhibitor (Z-VAD-FMK) or a caspase 1 inhibitor (Z-YVAD-FMK). Neither inhibitor affected metformin action (Figure 2D-2E), suggesting that metformin acts through a caspase-independent mechanism in the B16F10 melanoma cell line.

Necroptosis is a process of programmed cell death that acts independently of caspase activity and incorporates characteristics of both necrosis and apoptosis. RIPK1, RIPK3, and mixed-lineage kinase domain-like protein (MLKL) are receptor-interacting proteins that play a central role in the formation of the necrosome, a molecular structure that results in initiation of cell death [27]. In this regard, we assessed the viability of B16F10 cells treated with metformin in the presence of an RIPK1 inhibitor (necrostatin-1). The effect of metformin was partially inhibited by necrostatin-1 (Figure 2F). These findings suggest that RIPK1 may participate in the cell death process induced by metformin in B16F10.

The generation of reactive oxygen species (ROS) is an intracellular effect that can occur in different cell death processes, including apoptosis, necrosis, necroptosis, and even autophagy [28]. Detection of intracellular and
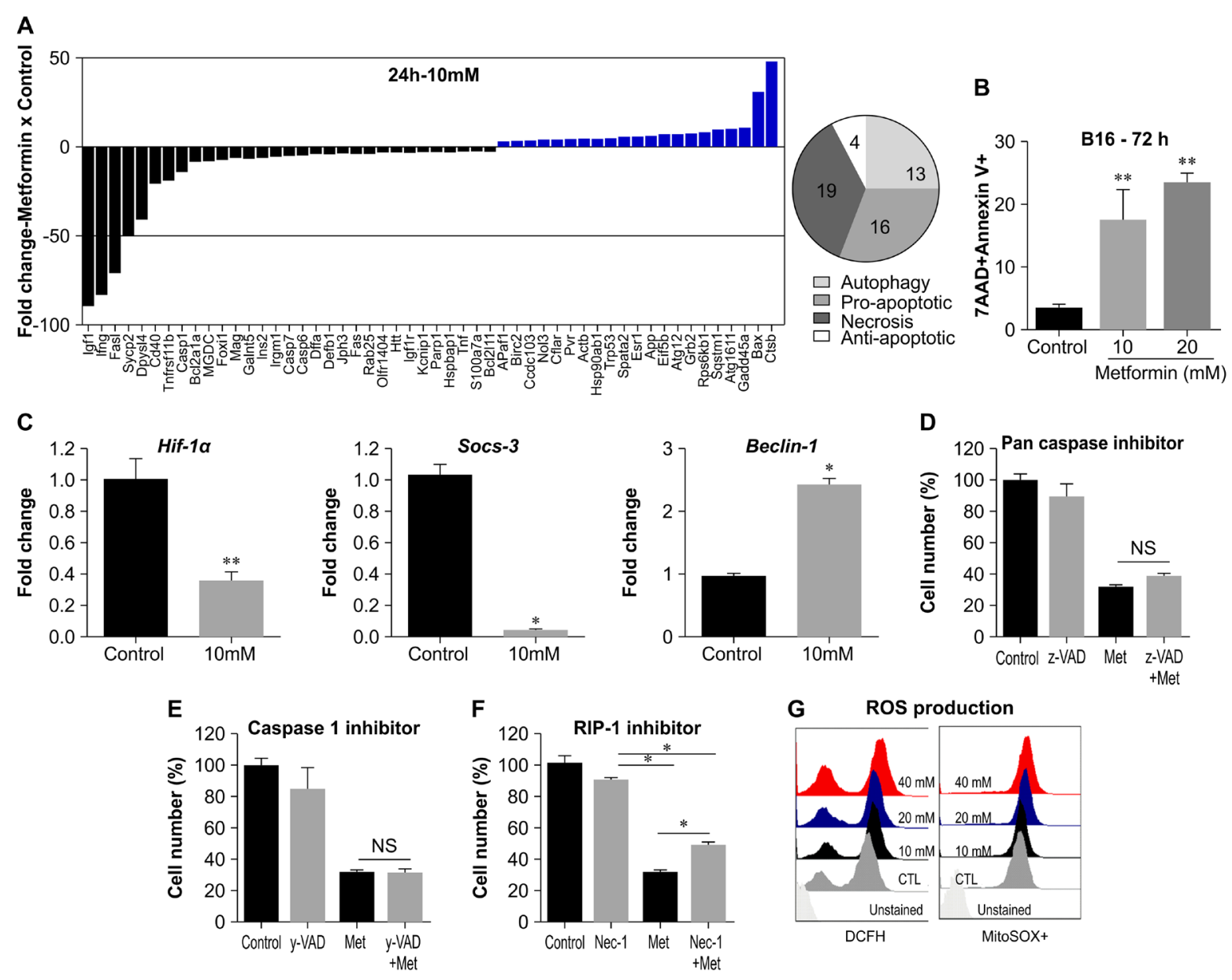

Figure 2: Metformin induces different cell death mechanisms in B16F10 melanoma cells. (A) Fold increase $(>2)$ or decrease $(<2)$ in gene expression after B16F10 cells were treated for $24 \mathrm{~h}$ with metformin $(10 \mathrm{mM})$, measured using quantitative RT-PCR. Pie chart shows the distribution of genes related to a specific cell death process. (B) B16F10 cells treated for $72 \mathrm{~h}$ with metformin $(10 \mathrm{Mm})$ were stained with annexin $\mathrm{V}$ and 7-AAD. (C) mRNA transcript quantification of HIF-1 $\alpha$, Socs-3, and Beclin-1 in B16F10 cells treated for $24 \mathrm{~h}$ with metformin $(10 \mathrm{mM})\left({ }^{* *} p<0.001\right)$. (D) B16F10 cells treated for 24 $\mathrm{h}$ with metformin $(20 \mathrm{mM})$ in the presence of Z-VAD-FMK $(20 \mu \mathrm{M})$, (E) Z-YVAD-FMK $(20 \mu \mathrm{M})$, (F) necrostatin-1 (Nec-1, $100 \mu \mathrm{M})$. Cell viability was measured using the MTT assay. (G) B16F10 cells were incubated for $24 \mathrm{~h}$ with metformin $(0-40$ $\mathrm{mM}$ ). Representative histograms and graphs of flow cytometry analyses showing mean fluorescent intensity of DCFH (left) or oxidized MitoSOX (right) following treatment. 
mitochondrial ROS in B16F10 was performed by flow cytometry using DCFH and MitoSox probes, respectively (Figure 2G). A dose-dependent increase was observed in intracellular (DCFH, left) and mitochondrial (MitoSox, right) ROS levels after treatment with metformin, compared with untreated cells (Figure 2G). Altogether, these data show that the effect of metformin on B16F10 cells involves multiple combined mechanisms associated with cell death.

\section{Anti-metastatic effects of metformin require an intact immune system}

To evaluate the anti-metastatic effects of metformin, C57BL/6 mice were inoculated intravenously with B16F10 murine melanoma cells and treated daily with metformin or vehicle for 12 days, starting 3 days after tumor cell challenge. The number of lung nodules was counted 24 $\mathrm{h}$ after the last dose of metformin. Oral administration of metformin significantly reduced the total number of lung metastases compared with control vehicle-treated mice (Figure 3A). Interestingly, we did not observe a protective effect of metformin in B16F10 melanoma cells inoculated subcutaneously (Supplementary Figure 2). Although metformin exerted a direct effect on melanoma cells, its influence on the tumor microenvironment in vivo and on the immune system has not been elucidated. To evaluate the role of immune effector function in metforminmediated reduction in B16F10 lung metastasis, we analyzed B16F10 tumor development in metformin-treated severely immunodeficient NSG mice. Corroborating our previous result, metformin treatment significantly reduced the number of lung metastases in C57BL/6 mice compared with metastases in untreated control mice (Figure $3 \mathrm{~B}$ ). Notably, the NSG mice group showed a significantly increased number of pulmonary nodules in comparison with C57BL/6 mice, and metformin-treated NSG mice presented a no significant difference in the number of lung nodules when compared with PBS-treated NSG mice (Figure 3B). These data suggest that the anti-metastatic effect of metformin is, at least in part, mediated by the immune system.

\section{Metformin treatment modulates local and systemic immune response}

To elucidate the immune pathways that contribute to the protective effect of metformin in metastatic melanoma, firstly we evaluated gene expression and protein levels of different cytokines in the lung tumor microenvironment. We observed an increased expression of Ifn $\gamma$ and $T n f \alpha$ genes in the lungs of metformin-treated mice compared with expression in the control group (Figure 4A). In contrast, Il10 and Il6 gene expression was unaffected by metformin compared with expression in the control group. Ill 17 gene expression was not detected in either group (Figure 4A). Protein levels of cytokines were measured by ELISA in lung homogenates on the $15^{\text {th }}$ day after B16F10 cell inoculation. There was a significant increase in the levels of TNF- $\alpha$ and IL-10, but no change in IL-1 $\beta$, IL-
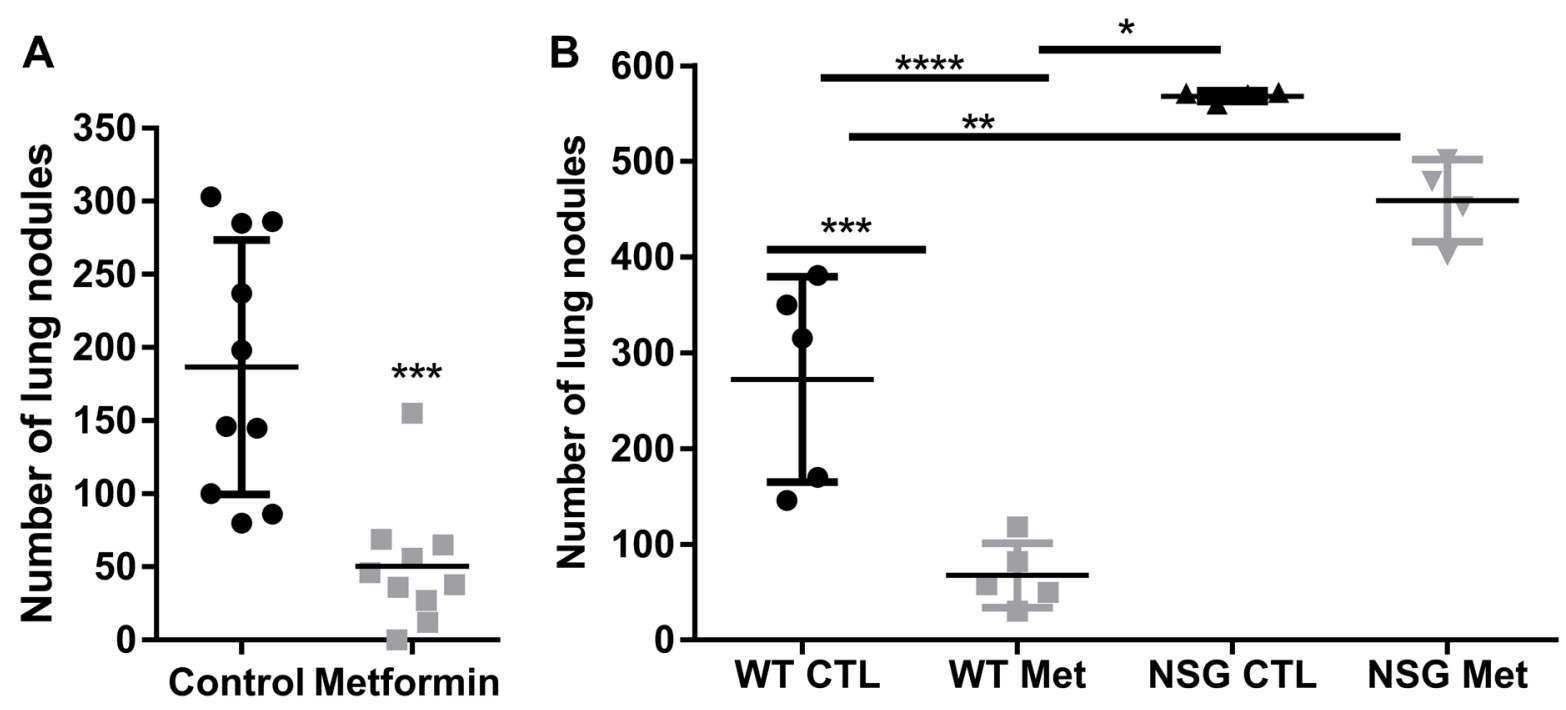

Figure 3: Anti-metastatic activity of metformin requires an intact immune system. (A) C57BL/6 mice were intravenously challenged with B16F10 cells, and treated by gavage with $500 \mathrm{mg} / \mathrm{kg}$ metformin or phosphate-buffered saline (PBS) daily from day 3 after challenge. Quantification of the number of lung nodules in each group, $\mathrm{n}=12,{ }^{* * *} p<0.0002$, mean \pm standard deviation. (B) B16F10 cells $\left(5 \times 10^{5}\right)$ were injected intravenously into C57BL/6 mice and NOD-SCID gamma null (NSG) mice. Three days after the challenge, the animals were treated with metformin $(500 \mathrm{mg} / \mathrm{kg})$ or PBS daily by gavage. Pulmonary nodules were counted on day $15 . \mathrm{n}=5$ animals per group $\left({ }^{*} p<0.05,{ }^{* *} p<0.001,{ }^{* * *} p<0.0001,{ }^{* * * *} p<0.001\right)$. 
6, and IL-17 expression in the lungs of the metformintreated group compared with expression in the control group (Figure 4B).

In addition to a local immune response, metformin treatment of B16F10-challenged mice induced a systemic antitumor response. Metformin-treated mice exhibited significantly increased TNF- $\alpha$, IL-10 and IL17 concentrations in splenocyte homogenates compared with concentrations in the control group, whereas IL-1 $\beta$ and IL-6 levels were similar in treated and untreated mice (Figure 4C). The levels of TNF- $\alpha$ significantly increased in the sera of the metformin-treated group compared to levels in the control group. Levels of adiponectin increased, and
IL-6 levels tended to decrease, but these findings were not statistically significant ( $p>0.05$ ) (Figure 4D). These results suggest that metformin modulates cytokine profiles locally and systemically in response to B16F10 challenge.

\section{Metformin treatment decreases Gr- $1^{+} C^{-} D 11 b^{+}$cells and increases $T$ cells infiltration into tumor}

We investigated whether metformin treatment affected immune cell populations involved in the antitumor effect, playing a protective role. First, the frequency of myeloid compartment cells was evaluated.
A

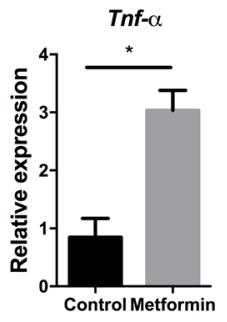

B
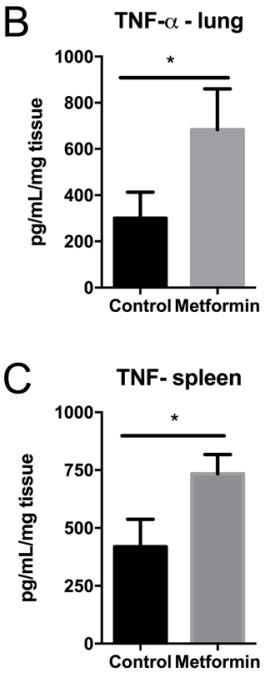

$\mathrm{D}$

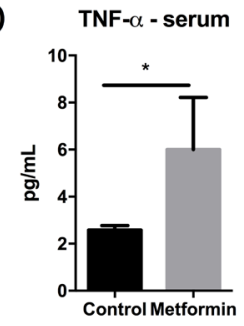

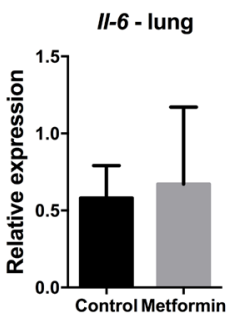

IL-6 - lung
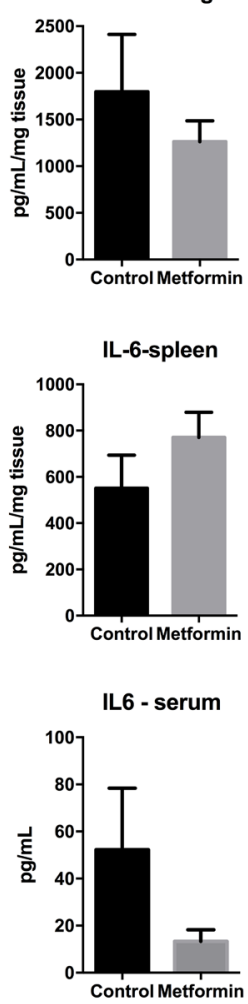
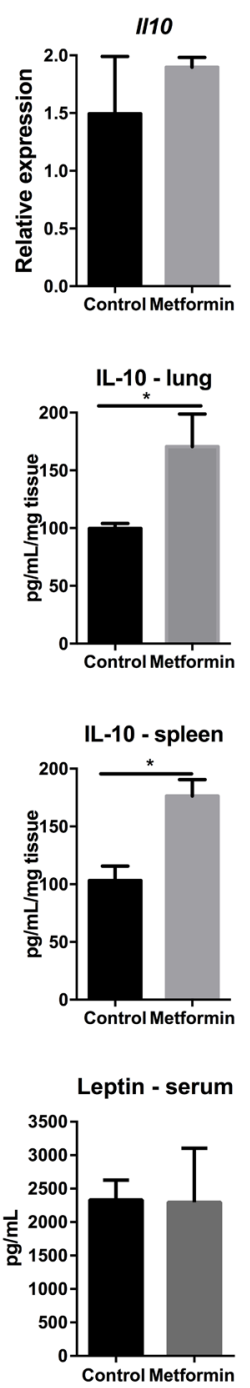
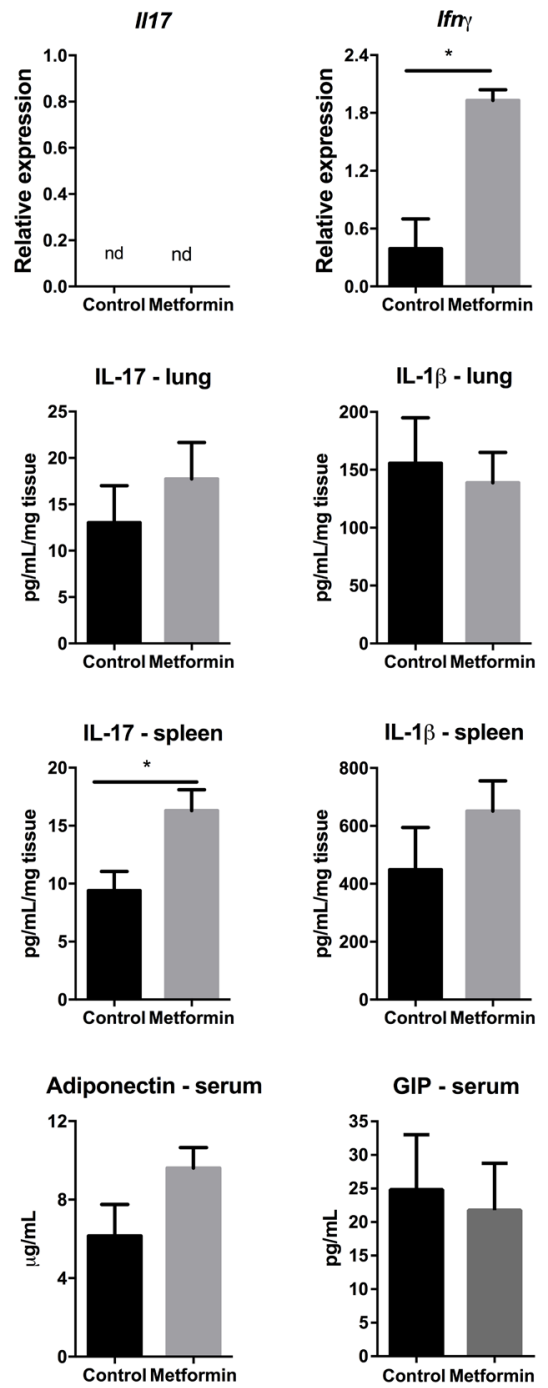

Figure 4: Tumor microenvironment and systemic profile of cytokines and hormones in mice treated with metformin. (A) Cytokine (IFN- $\gamma$, TNF- $\alpha$, IL-10, IL-6, and IL-17) mRNA expression was determined in the lungs of C57BL/6 mice challenged intravenously with B16F10 cells and treated with metformin. Values are expressed relative to a control group. The cycle thresholds $(\mathrm{Ct})$ for the gene and the internal control were determined for each sample. The relative mRNA expression was calculated as $2-\Delta \Delta C T$ relative to HPRT. Levels of the same cytokines were determined in the lungs (B) and spleen (C) of these animals by ELISA. (D) TNF- $\alpha$, IL-6, leptin, adiponectin, and GIP were measured in the sera of these mice by ELISA. $\mathrm{n}=5$; values are expressed as mean \pm standard error. ${ }^{*} p<0.05$. Images are representative of at least two independent assays. 
Macrophages $\left(\mathrm{CD} 11 \mathrm{~b}^{+} \mathrm{F} 4 / 80^{+}\right)$and dendritic cells $\left(\mathrm{CD} 11 \mathrm{c}^{+}\right)$in spleens were examined 15 days after the B16F10 challenge in metformin- and vehicle-treated C57BL/6 mice; no differences were observed (Figure $5 \mathrm{~A})$. Metformin treatment decreased the frequency of Gr$1^{+} \mathrm{CD} 11 \mathrm{~b}^{+}$cells in the spleen, cells with a myeloid-derived suppressor (MDSC) phenotype, which impair anti-tumor responses (Figure 5A).

Next, we analyzed the $\mathrm{T}$ cell subsets present in the lungs of metformin-treated C57BL/6 mice by flow cytometry, 15 days after i.v. challenge. The number of $\mathrm{CD}^{+} \mathrm{T}$ cells increased in the metformin-treated group compared with the control group (Figure 5B). Metformin also increased the numbers of $\mathrm{CD} 4^{+}$and $\mathrm{CD} 8^{+} \mathrm{T}$ cells, and of $\mathrm{CD} 8^{+} \mathrm{CD}^{2} 9^{+}, \mathrm{CD} 8+\mathrm{IFN} \gamma^{+}$, and $\mathrm{CD}^{+} \mathrm{Gzb}^{+} \mathrm{T}$ cells (Figure 5B-5C). Numbers of naïve $\mathrm{CD}^{+} \mathrm{T}$ cells $\left(\mathrm{CD} 44^{\mathrm{lo}} \mathrm{CD} 62 \mathrm{~L}^{\mathrm{hi}}\right)$ and central-memory $\mathrm{CD} 4^{+} \mathrm{T}$ cells $\left(\mathrm{CD} 44^{\mathrm{hi}} \mathrm{CD} 62 \mathrm{~L}^{\mathrm{hi}}\right)$ were similar between the metformintreated and control groups (Figure 5D). However, metformin treatment significantly increased the numbers of $\mathrm{CD}^{+}$effector-memory $\mathrm{CD} 8^{+} \mathrm{T}$ cells $\left(\mathrm{CD} 44^{\mathrm{hi}} \mathrm{CD} 62 \mathrm{~L}^{\mathrm{lo}}\right)$ in comparison with their numbers in the control group (Figure 5D). These results suggest that $\mathrm{T}$ cells lung infiltration is connected to the anti-metastatic response induced by metformin.

\section{$T$ cells are essential for the anti-metastatic effect of metformin}

To functionally determine whether $\mathrm{T}$ cells are involved in the anti-metastatic effect of metformin, we injected B16F10 melanoma cells into C57BL/6 (WT), $\mathrm{RAG1}^{-/}, \mathrm{CD}^{-/-}$, and $\mathrm{CD}^{-/-}$mice (Figure 6A). As previously observed, metformin reduced the number of lung nodules in the immunocompetent (WT) mice compared with the number of lung nodules in the control group. Although $\mathrm{RAG1}^{-/-}, \mathrm{CD}^{-/-}$and $\mathrm{CD}^{-/-}$ mice exhibited a significant reduction in the number of lung nodules compared to that in the WT group, we observed a higher lung nodules frequency in $\mathrm{RAG1}^{-/-}$, $\mathrm{CD}^{-/-}$and $\mathrm{CD} 4^{-/-}$hosts treated with metformin $(75 \%$, $60 \%$, and $76 \%$, respectively) compared with WT mice metformin-treated $(51 \%)$, (Figure 6A). To confirm whether the effects observed in $\mathrm{CD}^{-/-}$and $\mathrm{CD}^{-/-}$mice were directly related to the absence of these cells, CD8 and CD4 cells in WT mice were depleted in each subset 1 day prior, and 5 days after i.v challenge with B16F10 cells. After depletion of $\mathrm{CD} 8^{+} \mathrm{T}$ cells, metformin-treated and untreated animals showed similar number of lung nodules. However, depletion of $\mathrm{CD} 8^{+} \mathrm{T}$ cells abrogated metformin anti-metastasis effect in the melanoma model (Figure 6B). CD4-depleted animals showed a strong reduction in the number of lung nodules compared to nondepleted animals, showing that $\mathrm{CD} 4^{+} \mathrm{T}$ cells are important for metastatic melanoma development. Metformintreated, CD4-depleted mice also showed a reduction in the number of lung nodules compared to non-depleted mice (Figure 6C). These results suggest the importance of $\mathrm{T}$ lymphocytes in the protective response induced by metformin.

\section{Metformin treatment increases the population of $\mathrm{CD4}^{+} \mathrm{Foxp3}^{+} \mathrm{IL}^{+} \mathbf{1 0}^{+}$cells and decreases ROR- $\gamma^{+} \mathrm{IL}^{-17 \mathrm{~A}^{+} \mathrm{CD4}^{+} \mathrm{T} \text { cells in tumor-bearing mice }}$}

Based on our observation of a consistent increase in local and systemic IL-10 concentrations, associated with elevated numbers of $\mathrm{CD}^{+} \mathrm{T}$ cells in the lungs of metformin-treated tumor-bearing mice, we subsequently assessed whether Treg cells could be induced in this context. C57BL/6J mice were inoculated i.v. with B16F10 melanoma cells, and Foxp3 expression in the lungs was evaluated by real-time quantitative PCR. Metformin-treated animals showed a significant increase in Foxp3 gene expression compared with the control group (Figure 7A). We also injected B16F10 cells into Foxp3-gfp knock-in mice, which co-express EGFP and the regulatory $\mathrm{T}$ cell-specific transcription factor Foxp3 under the control of the endogenous promoter, and then treated these animals with metformin. Fifteen days after tumor challenge, the frequency of Foxp3-GFP ${ }^{+}$cells in the tumor draining lymph node (TDLN) and spleen of treated and untreated animals was analyzed by fluorescenceactivated cell sorting (FACS). Metformin-treated mice showed a significant increase in cell numbers in the lungs (Figure 7B), but not in the absolute numbers in the spleen (Figure 7C). To further investigate whether $\mathrm{CD}^{+} \mathrm{Foxp}^{+}$ cells induced by metformin in tumor-bearing mice were producing IL-10, $\mathrm{CD} 4^{+} \mathrm{T}$ cells were purified from the spleen of Foxp3-gfp knock-in mice and stimulated with phorbol myristate acetate (PMA) and ionomycin, followed by measurement of intracellular IL-10 levels (Figure 7D). IL-10 expression levels in CD4 $4^{+}$Foxp3-GFP ${ }^{-}$cells from metformin-treated and control groups were similar, but intracellular IL-10 expression in $\mathrm{CD}^{+} \mathrm{Foxp}^{-} \mathrm{GFP}^{+}$cells from mice treated with metformin was higher than in the untreated-control group (Figure 7D).

To determine how these $\mathrm{CD}^{+} \mathrm{Foxp} 3^{+} \mathrm{IL}-10^{+}$cells affect the anti-metastatic effects of metformin, we injected C57BL/6J mice with anti-CD25 1 day prior, and 1 and 7 days after B16F10 melanoma inoculation (Figure 7E). A reduction in the number of lung nodules was observed in CD25-depleted, melanoma-bearing untreated mice compared with non-depleted control mice. Curiously, the tumor protection induced by metformin was not altered when $\mathrm{CD} 25^{+}$cells were depleted, suggesting that $\mathrm{CD} 4^{+} \mathrm{Foxp} 3^{+} \mathrm{IL}-10^{+} \mathrm{T}$ cells induced by metformin treatment do not impair the observed antitumor effect. Previous work has shown that metformin can inhibit the differentiation of Th17 cells and thereby attenuate inflammatory and autoimmune diseases [15, 29]. As shown in Figure 7F, metformin decreased the percentage 
A

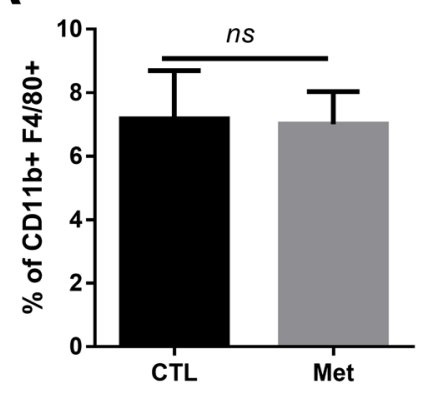

B

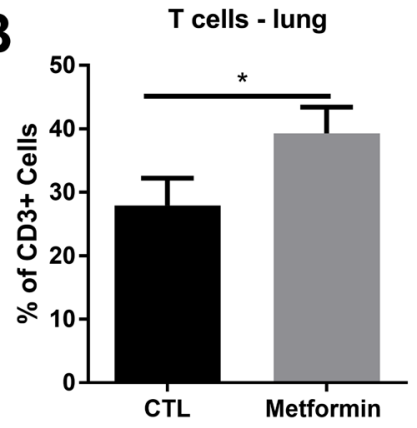

C

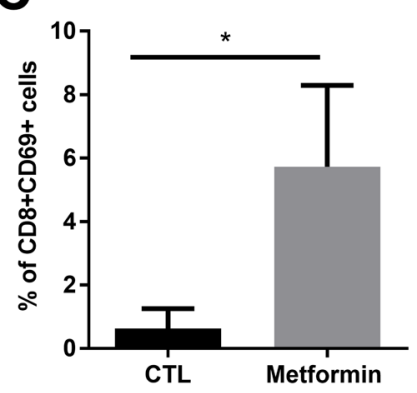

Daive T cells

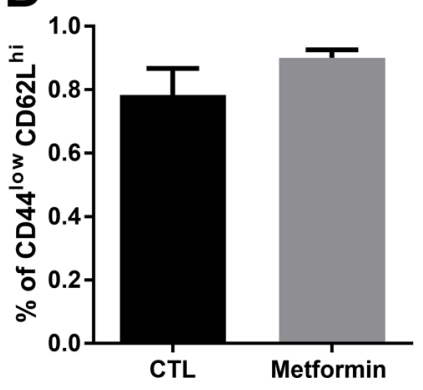

DC- spleen

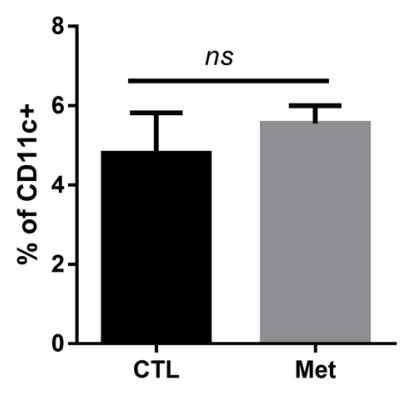

CD4 T cells - lung
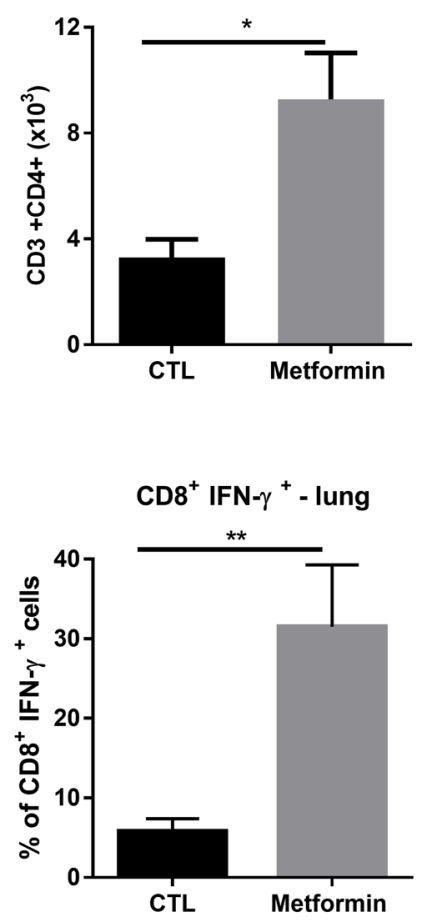

CD4 Effector-memory

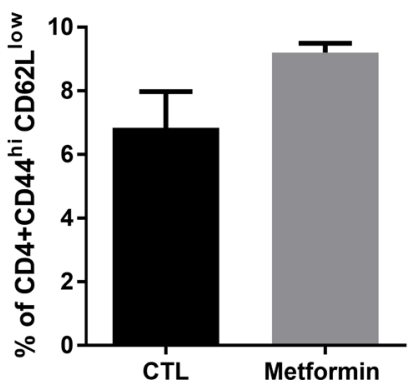

Gr-1 ${ }^{+}$CD $11 b^{+} \cdot$ spleen

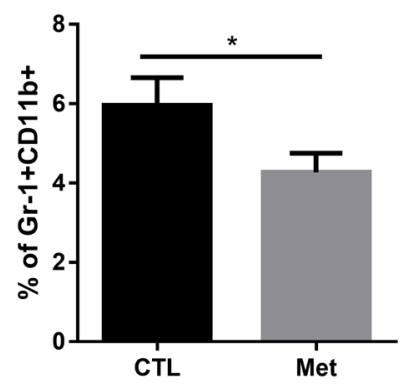

CD8 $\mathrm{T}$ cells - lung
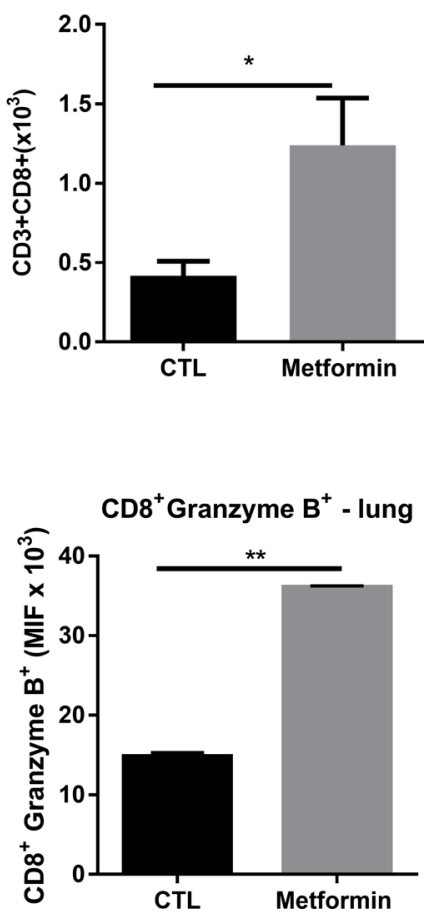

CD8 Effector-memory

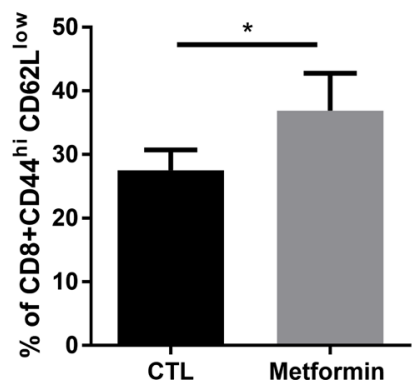

Figure 5: Effect of metformin on myeloid and T cells. (A) C57BL/6 mice intravenously challenged with B16F10 cells were treated with metformin or phosphate-buffered saline (PBS) and numbers of CD $11 \mathrm{~b}^{+} \mathrm{F} 4 / 80^{+}, \mathrm{CD} 11 \mathrm{c}^{+}$or Gr- $1^{+} \mathrm{CD} 11 \mathrm{~b}^{+}$cells were assessed in spleens by fluorescence-activated cell sorting. Percentage of T cells in the lung, absolute count of T CD4 ${ }^{+}$and T CD8 ${ }^{+}$lung cells (B), percentage of $\mathrm{CD}^{+} \mathrm{CD} 69^{+}, \mathrm{CD} 8^{+} \mathrm{IFN}-\gamma^{+}$, and $\mathrm{CD}^{+}$granzyme B ${ }^{+}$cells $(\mathbf{C})$. Number of naïve T cells, CD ${ }^{+} \mathrm{CD} 44^{\text {hi }} \mathrm{CD} 62 \mathrm{~L}^{\text {low }}$, and $\mathrm{CD} 8^{+} \mathrm{CD} 44^{\text {hi }} \mathrm{CD} 62 \mathrm{~L}^{\text {low }}$ cells (D). All quantities in absolute cell number or percentage \pm standard deviation. ${ }^{*} p<0.05$. 
of ROR- $\gamma^{+}$IL- $17 \mathrm{~A}^{+} \mathrm{CD} 4^{+} \mathrm{T}$ cells in lung tumor mice. In addition, metformin diminished polarization in vitro of CD4 ${ }^{+} \mathrm{IL}-17^{+} \mathrm{T}$ cells (Figure $7 \mathrm{G}$ ).

\section{Metformin combined with rapamycin or sitagliptin prevents lung metastasis}

Finally, we investigated the effects of metformin in combination with other target agents used for cancer treatment and other pathologies such as obesity, diabetes, and neurological disorders. We first evaluated rapamycin, a drug with well-described anticancer properties that acts as a specific inhibitor of the mTOR pathways $[30,31]$. Melanoma-bearing $\mathrm{C} 57 \mathrm{BL} / 6 \mathrm{~J}$ mice treated intraperitoneally with rapamycin in combination with metformin showed a significant reduction in the number of metastatic lung nodules compared with that in untreated control mice and mice treated with each drug separately (Figure 8A). Next, we similarly evaluated sitagliptin $\left(\right.$ Januvia $^{\circledR}$ ), which is a selective inhibitor of dipeptidyl peptidase 4 (DPP-4), and is used as monotherapy or in association with other anti-diabetic drugs (i.e. metformin) in the treatment of T2D. Treatment of melanoma-bearing C57BL/6J mice with metformin or sitagliptin resulted in a significant reduction in the number of metastatic lung nodules compared with the number of nodules in control mice (Figure 8B). Treatment with metformin and sitagliptin together showed a greater reduction in the number of metastatic lung nodules than did treatment with metformin or sitagliptin alone (Figure 8B).

Several reports have shown that metformin and sitagliptin exert an "off-target" effect on T cells [32]. No
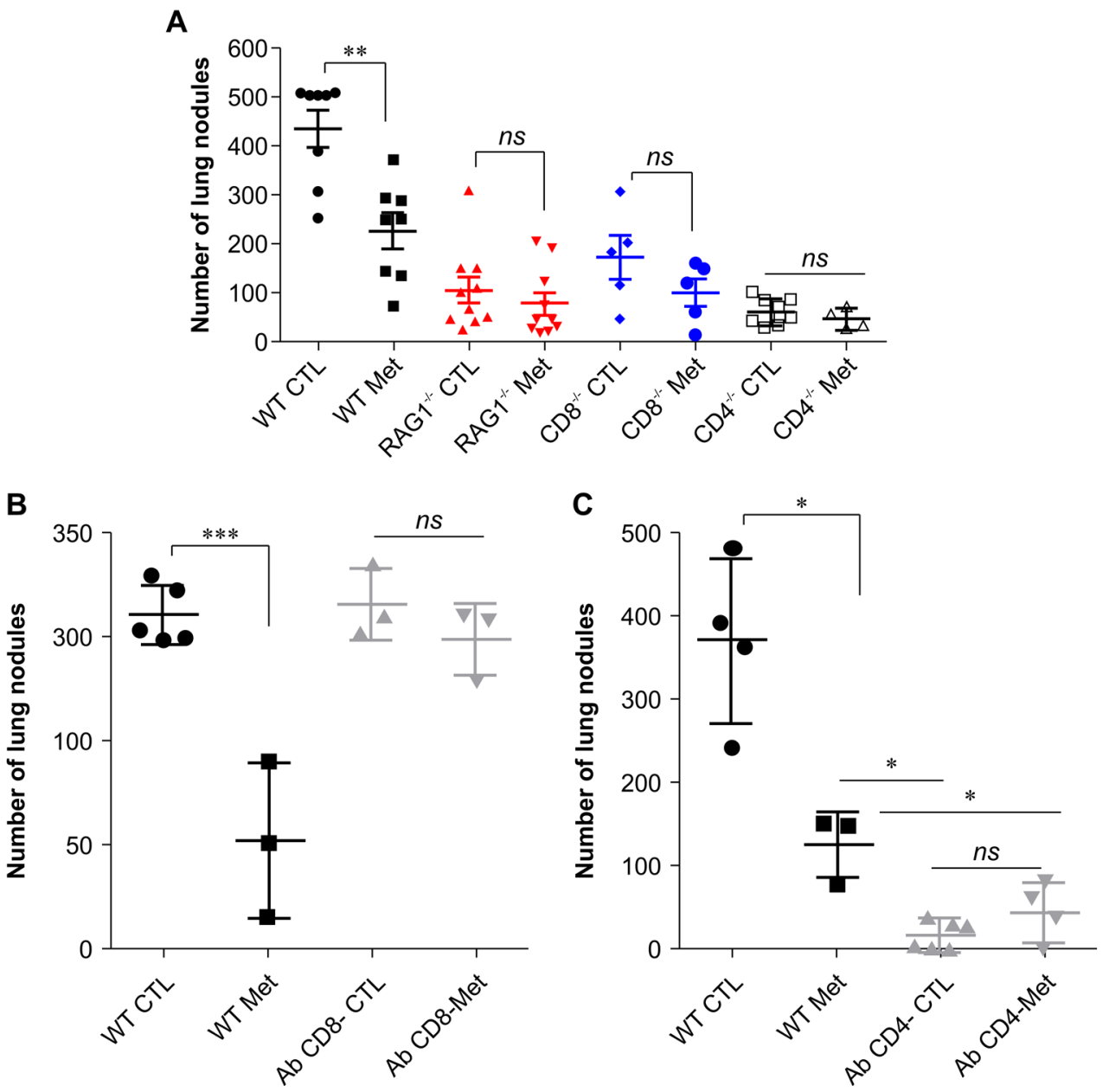

Figure 6: (A) Anti-metastatic activity of metformin with $\mathrm{T}$ cell participation. B16F10 cells $\left(5 \times 10^{5}\right)$ were injected intravenously into $\mathrm{C} 57 \mathrm{BL} / 6, \mathrm{RAG}^{-/}, \mathrm{CD}^{-/}$, or $\mathrm{CD}^{-/-}$mice, and the animals were treated with metformin or phosphate-buffered saline (PBS) (n=5-11, pooling at least two experiments). ${ }^{*} p<0.05,{ }^{* *} p<0.01$. (B) B16F10 cells $\left(5 \times 10^{5}\right)$ were injected intravenously into C57BL/6 mice treated with metformin or PBS; the animals were administered $200 \mu \mathrm{g}$ of an anti-CD8 antibody intraperitoneally on days 3,7 , and 11 . $\mathrm{n}=4-5 \mathrm{mice}$ per group $\left({ }^{*} p<0.05\right)$. (C) B16F10 cells $\left(5 \times 10^{5}\right)$ were injected intravenously into C57BL/6 mice treated with metformin or PBS; the animals were administered $500 \mu \mathrm{g}$ of an anti-CD4 antibody intraperitoneally on days 1 and $5 . \mathrm{n}=4-5$ mice per group $\left({ }^{*} p<0.05\right)$. Values are expressed as mean \pm standard deviation. 

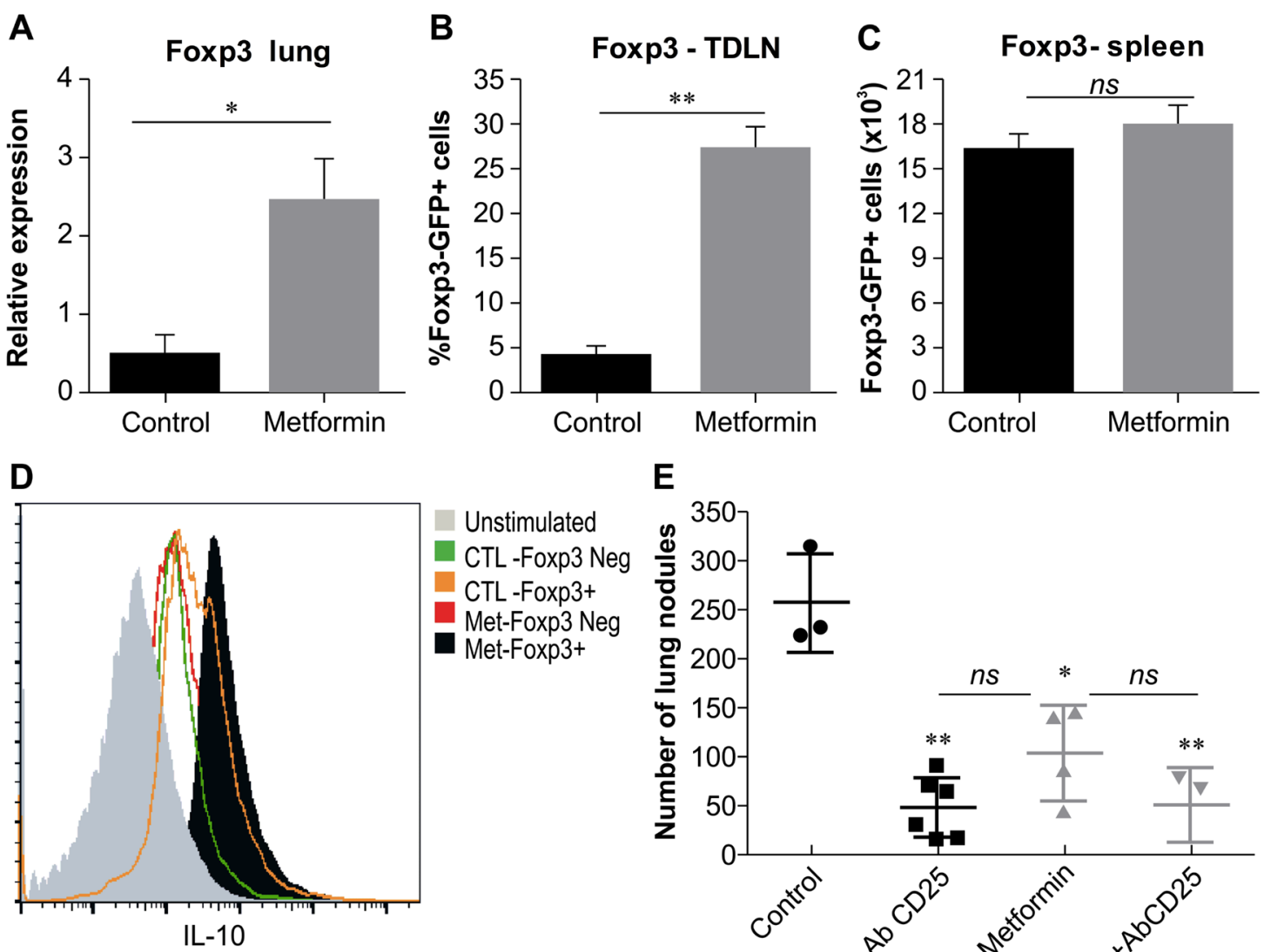

$\mathbf{F}$

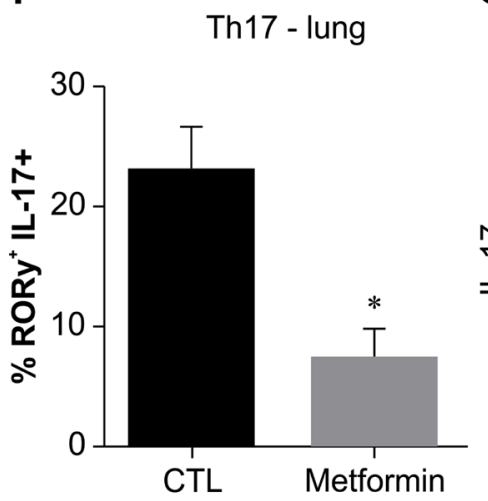

G

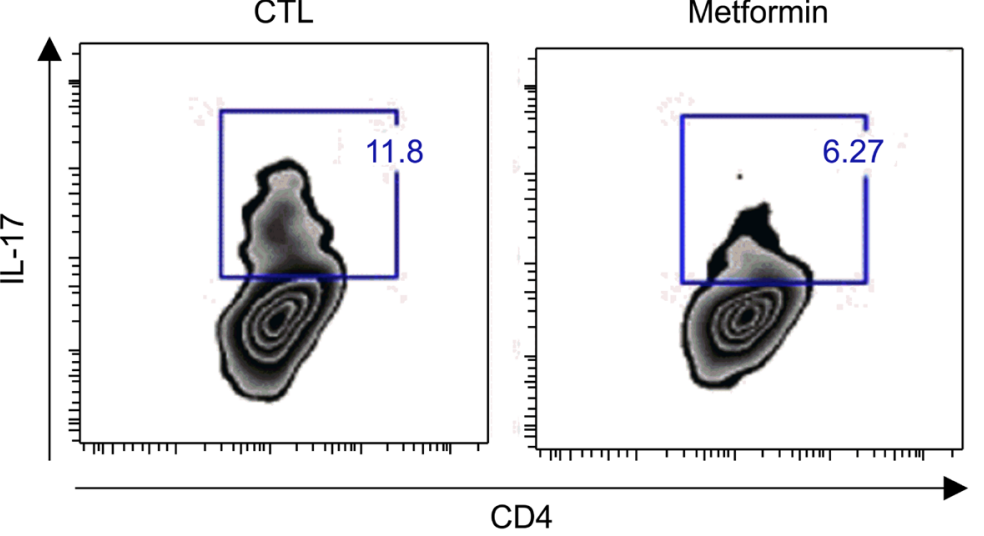

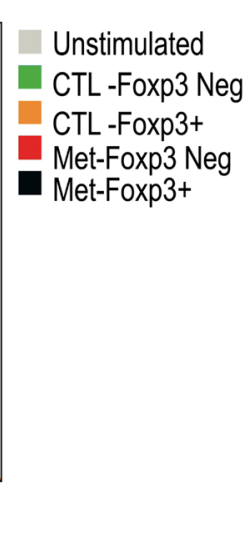

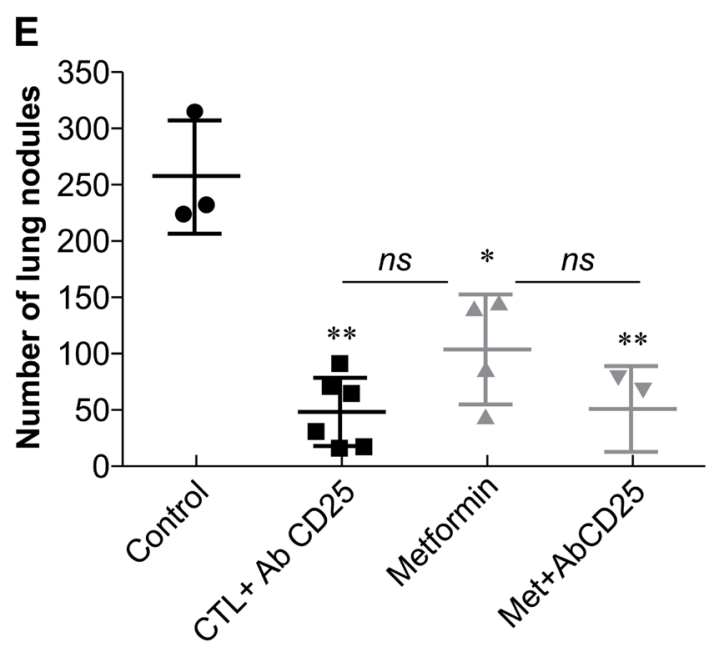

E

CTL

Metformin

Figure 7: Metformin treatment induces an increase in CD4+Foxp3+IL-10+ cells in vivo. (A) C57BL/6 mice were intravenously challenged with B16F10 cells, and treated by gavage with $500 \mathrm{mg} / \mathrm{kg}$ metformin or phosphate-buffered saline (PBS) daily from day 3 after challenge. Foxp3 mRNA expression in the lung tumor burden was measured by real-time PCR on day 15 after tumor challenge. Number of total Foxp3 ${ }^{+} \mathrm{GFP}^{+}$cells from TDLN (B) or spleen (C) of Foxp3-gfp mice intravenously challenged with B16F10 cells and treated by gavage with metformin or phosphate-buffered saline (PBS). (D) Sorted Foxp3 $3^{+}$or Foxp3 $3^{-}$cells were stimulated with phorbol myristate acetate (PMA) and ionomycin (IOM) and then stained for intracellular IL-10 from the spleens of Foxp3-gfp knock-in mice challenged with B16F 10 cells and treated by gavage with $500 \mathrm{mg} / \mathrm{kg}$ metformin or PBS for 15 days. (E) Mice were treated with intraperitoneal injection on days 1, 4, and 7 of anti-CD25 (500 $\mu \mathrm{g} /$ dose), followed by treatment with metformin (500 $\mu \mathrm{g} / \mathrm{mouse})$. (F) Number of CD4 ${ }^{+} \mathrm{ROR} \gamma^{+} \mathrm{T}$ cells in the lungs of mice intravenously challenged with B16F10 cells and treated with metformin. (G) Naïve CD4 ${ }^{+} \mathrm{T}$ cells were sorted from C57BL/6J mice and cultivated in the presence of TGF- $\beta(1 \mathrm{ng} / \mathrm{mL}), \mathrm{IL}-6(50 \mathrm{ng} / \mathrm{mL})$, and anti-CD3/antiCD28 with or without $10 \mathrm{mM}$ of metformin. Relative mRNA expression was calculated as $2-\Delta \Delta C$ T relative to HPRT. $\mathrm{n}=3$; values are expressed as mean \pm standard error. ${ }^{*} p<0.05,{ }^{* *} p<0.01$. Images are representative of at least two independent assays. 
significant difference in the number of metastatic lung nodules was observed between metformin/sitagliptintreated mice and the untreated control group when the experiment was performed on $\operatorname{Ragl}^{-/-}$mice (data not shown). Overall, these results indicate that the antidiabetic metformin and sitagliptin exert an anti-tumor immune response by affecting $\mathrm{T}$ cell performance.

\section{Metformin combined with sitagliptin exerts a strong effect in the BRAF/PTEN mouse model}

Mutations in the serine/threonine kinase BRAF are the most common genetic alterations in human melanoma; however, B16F10 murine melanoma cells do not present this mutation [33]. We therefore tested whether a metformin/sitagliptin combination could also exert an effect in a murine tumor model with conditional melanocyte-specific expression of BRAF (V600E). In this melanoma pre-clinical model, Tyr:CreER:Braf ${ }^{\mathrm{CA}}:$ Pten $^{\text {lox }} / \mathrm{lox}$ (BRAF/PTEN), topical application of 4-hydroxytamoxifen
(4-HT) to the skin induces an active Braf V600E mutation and Pten deletion in melanocytes [34, 35]. Five days after 4-HT applications to BRAF/PTEN mice, we initiated treatment with metformin/sitagliptin by gavage for 40 consecutive days. Metformin/sitagliptin-treated BRAF/ PTEN mice showed a significant increase in median survival compared to that reported for untreated BRAF/ PTEN mice (Figure $8 \mathrm{C}$ ). These results confirm that the effect of the metformin/sitagliptin combination on B16F10 cells was similar to the effect on melanoma cells harboring the BRAF mutation.

\section{DISCUSSION}

The results of this study showed that metformin can not only induce the cell death process but also exert a strong immunomodulatory effect, which can be enhanced by combination with other metabolism-targeting drugs to treat melanoma metastases. Recent studies have demonstrated that metformin acts on the immune system
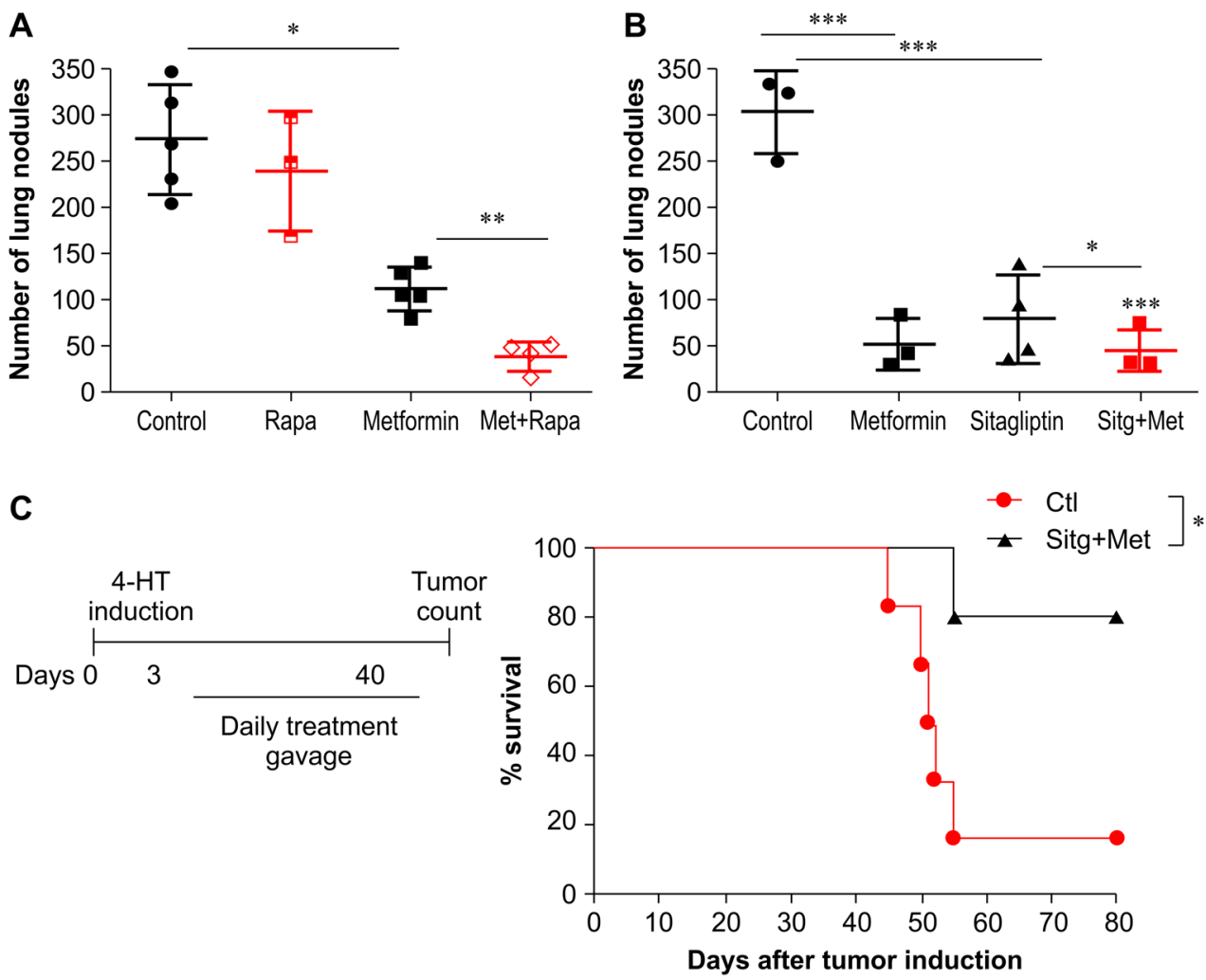

Figure 8: Anti-metastatic effect of metformin in combination with rapamycin or sitagliptin in a BRAF V600 murine model. (A) C57BL/6 mice intravenously challenged with B16F10 cells $\left(5 \times 10^{5}\right)$ were treated with phosphate-buffered saline (PBS), metformin $(500 \mathrm{mg} / \mathrm{kg}$ ), rapamycin (rapa, $1.5 \mathrm{mg} / \mathrm{kg}$ ), or metformin + rapa, starting 3 days after challenge ( $\mathrm{n}=3-5)$. The number of lung nodules was evaluated 15 days after the challenge. (B) C57BL/6 mice intravenously challenged with B16F10 cells $\left(5 \times 10^{5}\right)$ were treated with PBS, metformin, sitagliptin $(50 \mathrm{mg} / \mathrm{kg}$ ), or sitagliptin/metformin starting 3 days after the challenge (n=3-4). (C) Kaplan-Meier survival curves comparing Tyr:CreER; BrafCA/+ and Ptenlox/lox mice treated with sitagliptin/metformin 45 days after topical administration of 4-hydroxytamoxifen (4-HT); pool of two independent assays evaluated by the log-rank test $(\mathrm{n}=7-8)$. Animals are represented individually; mean and standard deviation are shown by horizontal lines. ${ }^{*} p<0.05 ;{ }^{* *} p<0.001 ;{ }^{* * *} p<0.0001$; ns, not significant. 
in various disease therapies [14, 36, 37]. In this, we showed that treatment of human and murine melanoma cells with metformin in vitro induces cell death through pleiotropic mechanisms.

Molecules involved in autophagy, such as ATG17, Beclin-1, and cathepsin B, or molecules associated with apoptosis, such as Bax, HIF-1 $\alpha$, and SOCS3 were up-regulated by metformin treatment. These data are consistent with those reported in previous studies on melanoma and other tumors [38-40]. However, in this study, metformin was also found to induce a caspaseindependent death pathway as well as RIPK1, a key molecule in necroptosis. The role of RIPK1 in autophagy is not yet clearly understood, although a recent report suggested that RIPK1 represses basal autophagy via ERK-mediated phosphorylation of transcription factor EB [41]. Castration-resistant prostate cancer cells treated with metformin and simvastatin were shown to induce Ripk1- and Ripk3-dependent necrosis, suggesting that these necroptosis molecules may be important in the antitumor effects mediated by metformin [42]. The caspase-independent effects demonstrated here were also observed in cardiomyocytes [43]. The in vitro migration of human melanoma cells significantly decreased in the presence of metformin, at a dose that did not affect the viability of cells. This suggests that the drug, even at suboptimal doses, could affect tumor development. Recently, Liang et al. showed that 2.5- and 5-mM doses of metformin up-regulated the expression of E-cadherin in B16F10 cells, inhibiting cell motility, migration, and invasion, in a dose-dependent manner [44]. We know that primary cells derived from different patients can behave differently in culture conditions, and the expression of genes important to metformin's effect could be dramatically different between cells lines with distinct origins. Sensitivity to metformin may also be mediated by expression levels of the organic cation transporters (OCT1, OCT2, and OCT3). OCT1 is primarily responsible for metformin transport into cells, and polymorphisms in the gene encoding OCT1 that affect hepatic uptake of metformin in vitro have been associated with decreased efficacy in patients [45]. However, there is little information on the expression of OCT1 in human tumors. Thus, expression of these receptors, among others factors, may contribute to metformin resistance in different patient cell lines.

However, the direct effects of metformin on melanoma cells alone cannot fully account for the potent anti-metastatic activity that was observed in vivo in B16F10 melanoma model. In fact, our studies with NSG mice showed that immune system activation is necessary for the anti-metastatic activity of metformin, and metformin treatment induces a local and systemic cytokine response. This is in line with a recent report that the antitumor effect of metformin may be mediated mainly via the immune system [46]. The study demonstrated that metformin can increase the number of $\mathrm{CD} 8^{+} \mathrm{T}$ cells infiltrating tumors and protect cells from apoptosis and depletion, as characterized by decreased production of IL-2, TNF- $\alpha$, and IFN- $\gamma$ [46]. In this study, we observed that metformin decreased the number of $\mathrm{Gr}^{+} \mathrm{CD} 11 \mathrm{~b}^{+}$ cells in the spleen of tumor-bearing mice. These cells are phenotypically similar to MDSCs, which are important suppressors of the tumor immune response and include two major subsets: i) $\mathrm{CD} 11 \mathrm{~b}^{+} \mathrm{Ly}_{6 \mathrm{G}}+$, which are immature granulocyte cells, and ii) $\mathrm{CD}_{11} \mathrm{~b}^{+} \mathrm{Ly} 6 \mathrm{C}^{+}$, which are immature monocytic cells [47].

Although a systemic increase in IFN- $\gamma$ and TNF- $\alpha$ was observed, IL-10 expression increased in the tumorbearing mice treated with metformin. Modulation of these opposing cytokines by metformin may reflect the high number of tumor-infiltrating lymphocytes (TIL) in treated mice. Our results suggested an important role for $\mathrm{T}$ lymphocytes in the protective immune response induced by metformin treatment of B16F10 melanomabearing mice. $\mathrm{CD}^{+} \mathrm{CD} 9^{+}$and $\mathrm{CD}^{+}$effector-memory increased in metformin-treated mice, and $\mathrm{CD} 8^{+}$depletion reduced the anti-metastatic effect of metformin. $\mathrm{CD}^{+} \mathrm{T}$ cells are also important to the anti-metastatic effect of metformin in our model. The effect of metformin was attenuated in $\mathrm{CD}^{+/-}$knockout mice and in $\mathrm{CD}^{+}$depletion assays. Recent reports have shown that $\mathrm{CD} 4^{+} \mathrm{T}$ cells have different mechanisms to enhance effector and memory $\mathrm{CD}^{+} \mathrm{T}$ cell functions, which may explain this result [48, 49]. We therefore believe that a possible interpretation of our results is the requirement of $\mathrm{CD}^{+} \mathrm{Th}$ cells for activation of $\mathrm{CD}^{+}$CTLs [50]. Furthermore, several findings indicate a role for $\mathrm{CD}^{+} \mathrm{T}$ cells in antitumor responses beyond providing support for CD8 ${ }^{+}$CTLs [48, 51]. Worth to remember that the lower number of lung nodules in $\mathrm{RAG}^{-/-}$mice in the B16F10 metastatic model has already been observed [52]. These authors reported that mice lacking $\mathrm{T}$ cells, or depleted of $\mathrm{CD}^{+}$and $\mathrm{CD}^{+} \mathrm{T}$ cells, were resistant to pulmonary B16 growth, but not to subcutaneous growth.

In the lungs of tumor-bearing mice, it was observed a significant increase in the numbers of $\mathrm{CD}^{+} \mathrm{Foxp}^{+} \mathrm{IL}-10^{+}$and a significant decrease in ROR$\gamma^{+}$IL-17A $\mathrm{AD}^{+}{ }^{+} \mathrm{T}$ cells $\mathrm{T}$ cells in metformin-treated and protected animals, phenotypically similar to Treg and Th17 cells, respectively. Several studies have reported that metformin can ameliorate inflammatory and autoimmune diseases by regulating the Th17/Treg balance $[15,29,53]$. Increased numbers of Treg cells after treatment with metformin was observed for RL male 1 leukemia cells [46]. Th17 down-regulation by metformin has also been demonstrated in a hepatocellular carcinoma model associated with a decrease in IL-22 secretion, as well as a transient increase in Treg cells in a leukemia solid tumor model $[14,46]$. Although 
Tregs are associated with tumor development, one study demonstrated that IL-10 from Tregs induced by type I IFN is necessary to negatively regulate Th17 inflammation in the tumor microenvironment [54]. In addition, evaluation of bacterial and viral murine models demonstrated that Tregs induce high-avidity $\mathrm{CD}^{+} \mathrm{T}$ cells in primary responses and promote maturation of $\mathrm{CD}^{+}$ $\mathrm{T}$ cells in the resolution phase of infection [49, 55]. Despite this, it is necessary a better understanding about the mitochondrial impact of metformin on T cells present in tumor microenvironment. Mitochondria is the first intracellular target of metformin where this drug inhibits the complex I of the electron transport chain, leading to a drop-in energy load $[56,57]$. The specific molecular mechanisms involved in inhibition of the mitochondrial complex I remain obscure. It has been reported that there is an interaction between biguanides and mitochondrial copper ions, and this interaction seems to be crucial for the metabolic effects of metformin [58]. Previous research has shown that this effect in the mitochondria is important for the antitumoral activity of metformin [59]. Also, recently it was reported that mitochondrial activation on $\mathrm{T}$ cells increases CTL function against tumor $[60,61]$.

Several agents targeting cancer metabolism have potential therapeutic value [62]. However, only a few of these drugs have been evaluated in relation to their effects on others cells in the tumor microenvironment, particularly for immune system cells. Metformin, rapamycin, and sitagliptin are clinical drugs with wellknown metabolic features. Some studies have shown both anticancer action of and modulation of immune cells by these agents [6, 63-65]. Rapamycin has an antimetastatic effect and can influence $\mathrm{T}$ cell biology via mTOR modulation $[63,66]$. It may also cooperate with anti-CTLA-4 to increase $\mathrm{CD}^{+} \mathrm{T}$ cell memory [66]. Our findings suggest that a metformin/sitagliptin combination may contribute to treating melanoma with different driver mutations, including melanoma with or without a BRAF (V600E) mutation. Sitagliptin, a specific DPP-4 inhibitor, has an important effect on $\mathrm{CD}^{+} \mathrm{T}$ cells in addition to its anti-diabetic effects, and a recent report showed that DPP4 inhibition could increase lymphocyte trafficking, thereby improving antitumor immunity by CXCL10 preservation $[32,67]$. Drug combinations targeting T cell immunometabolism could prevent allograft rejection [30]. Several clinical trials are currently using metformin alone or in combination with others agents, including immune checkpoint inhibitors [68].

In this study, we report that the antitumor effect of metformin besides the induction of cell death, with distinct features, rely on immune cells in special $\mathrm{T}$ cells present in the tumor microenvironment. Moreover, we offer evidence supporting that metformin combined with other clinical metabolic drug targets, such as MTOR and DPP4 inhibitors, could be repurposing as a strategy for treating cancer.

\section{MATERIALS AND METHODS}

\section{Ethics statement}

The investigation was conducted in accordance with ethical standards and national and international guidelines. All animal experiments were approved by the Animal Experimentation Ethics Committee of the Institute of Biomedical Sciences of the University of São Paulo (CEUA number: 017-2015).

\section{Cell lines}

All experiments were performed with murine melanoma B16F10 cells, deposited at BCRJ (Rio de Janeiro Cell Bank, Brazil) code 0046. The melanoma patient cell lineages were kindly provided by M.D. Ph.D. Débora C.P. Silva (Ludwig Institute for Cancer Research, São Paulo). The cell lines MEL11, MEL26, and MEL28 [69] were cultured in RPMI 1640 medium (Invitrogen, Carlsbad, CA, USA) supplemented with $24 \mathrm{mM}$ sodium bicarbonate, $10 \mathrm{mM}$ HEPES (Sigma-Aldrich, St. Louis, MO, USA), 40 mg/L gentamicin (Gibco, Carlsbad, CA, USA), pH 7.2, and 10\% fetal bovine serum (FBS, Gibco), and maintained frozen in liquid nitrogen. After thawing a frozen aliquot, cells were used until a maximum of 4 growth cycles.

\section{Animals and in vivo assays}

$\mathrm{C} 57 \mathrm{BL} / 6, \mathrm{RAG}^{-/-}, \mathrm{CD}^{-/-}, \mathrm{CD}^{-/}$, and Foxp3eGFP mice, 6-8 weeks old, were purchased from our Isogenic Breeding Unit (Immunology Department, Biomedical Science Institute, University of São Paulo). NSG mice (NOD scid gamma or NOD.Cg-Prkdcscid Il2rgtm $1 \mathrm{Wj} / \mathrm{SzJ}$ ) were purchased from the Center for Development of Experimental Models (CEDEME), at UNIFESP. Mice were injected intravenously via the caudal vein with $5 \times 10^{5}$ B16F10 melanoma cells $(0.1 \mathrm{~mL} / \mathrm{mouse})$. Three days after tumor cell challenge, metformin (Merck, Kenilworth, NJ, USA; 500 mg/kg/day), rapamycin (SigmaAldrich; $1.5 \mathrm{mg} / \mathrm{kg}$ ), sitagliptin (Januvia, Merck; $50 \mathrm{mg}$ / $\mathrm{kg}$ ), or PBS was administered daily by gavage until the $14^{\text {th }}$ experimental day. Lung metastatic nodules were counted using an inverted microscope on the $15^{\text {th }}$ day. For depletion assays, $\mathrm{C} 57 \mathrm{Bl} / 6 \mathrm{~J}$ mice were treated by intraperitoneal injection with monoclonal antibodies, clones GK1.5 to deplete $\mathrm{CD}^{+}$or clones PC61 to deplete CD25+. GK1.5 $(500 \mu \mathrm{g} /$ dose $)$ to deplete $\mathrm{CD}^{+}$was inoculated 72 and $24 \mathrm{~h}$ before i.v. tumor cell challenge; P61 (500 $\mu \mathrm{g} / \mathrm{dose})$ was inoculated $24 \mathrm{~h}$ prior, and also 4 and 7 days after tumor cell challenge. Tyr-CreERt: BrafCA:Ptenlox/lox, a transgenic murine model of BRAF V600 mutation in a heterozygous genetic background, (Jackson laboratory, Bar Harbor, ME, USA) was intradermally injected (i.d.) with 4-hydroxytamoxifen (4-HT) in the back for mutation 
induction. Treatment with metformin and sitaglipitin iniciated on the $5^{\text {th }}$ day after 4-HT inoculation.

\section{Cell viability assay}

B16F10 and melanoma patient tumor cells were plated onto 96 -well plates $\left(5 \times 10^{4}\right.$ cells $\left./ \mathrm{mL}\right)$ and treated with different concentrations of metformin (Merck) for 24,48 , or $72 \mathrm{~h}$. Viable cells were determined by the MTT assay (Sigma-Aldrich). We also assessed cellular viability by measuring extracellular lactate dehydrogenase (LDH) in culture media using a colorimetric method (Labtest, Vista Alegre, MG, Brazil). Where indicated, cells were incubated with caspase-family inhibitor Z-VAD fluoromethylketone (Z-VAD-FMK, Biovision, USA) $2 \mathrm{mM}$, caspase-1 inhibitor (Z-YVAD-FMK, Biovision, USA) and the necroptosis inhibitor necrostatin-1 (nec-1, Sigma-Aldrich) at a concentration of $10 \mu \mathrm{M}$.

\section{Migration wound-healing assay}

Tumor melanoma cells were plated onto 6-well plates $\left(1 \times 10^{6}\right.$ cells $\left./ \mathrm{mL}\right)$ in triplicate. After cell attachment and growth to a confluent monolayer (higher than $80 \%$ ), the medium was pipetted out and replaced by PBS, and one scratch wound was made with a P1000 tip (Thermo Fisher Scientific, Waltham, MA, USA) in each well. PBS was pipetted out, serum-free RPMI medium with metformin was added to each well, and cells were incubated for 3 , 7 , and $24 \mathrm{~h}$. The cell migration distance was determined by measuring the width of the wound and subtracting this value from the initial half-width value of the wound.

\section{Gene profiles and qPCR}

Total RNA was isolated from the spleen and lung samples that were snap-frozen in liquid nitrogen or B16F10 cultures treated with or without metformin by using TRIzol reagent (Invitrogen) according to the manufacturer's instructions. RNA concentrations were determined by spectrophotometry readings at 260 nm. First-strand cDNA was synthesized using MMLV reverse transcriptase (Promega, Madison, WI, USA). RTPCR was performed using the Taqman real-time PCR assay (Applied Biosystems, Foster City, CA USA) for the following molecules: HPRT (Mm00446968 m1), TNF- $\alpha$ (Mm00443258 m1), IL-6 (Mm004461690_m1), SOCS3 (Mm00545913_s1), IFN $\gamma\left(\mathrm{Mm00801778 \_ m1),}\right.$ IL-10 (Mm439616 m1), FOXP3 (Mm00475156 m1), RORc (Mm01261022 m1), HIF1a (00468878 m1), IL-1 $\beta$ (Mm00434228_m1), IL-17 (Mm00439619_m1), and Beclin-1 (Mm01265461_m1). Cycling conditions were as follows: Ten minutes at $95^{\circ} \mathrm{C}$ followed by 45 cycles at $20 \mathrm{~s}$ each at $95^{\circ} \mathrm{C}, 20 \mathrm{~s}$ at $58^{\circ} \mathrm{C}$, and $20 \mathrm{~s}$ at $72^{\circ} \mathrm{C}$. Sequence Detection Software 1.9 (SDS) was used for analysis. mRNA expression was normalized to HPRT expression, calculated with the following equation: Relative expression level of the target mRNA $=2-\Delta \Delta$ Ct. The cell death PCR array (PAMM-212Z, SABiosciences, Frederick, MD, USA), with primers for 84 pathway-specific genes, was performed according to the manufacturer's instructions.

\section{Flow cytometry}

Foxp3-GFP ${ }^{+}$cells and $\mathrm{T}$ subset cells were analyzed by multicolor flow cytometry. The monoclonal antibodies used were CD3, CD4, CD8, CD44, CD62L (BD Biosciences, Franklin Lakes, NJ, USA), CD11b, CD11c, F4/80, Ly6G, and Ly6C (BioLegend, San Diego, CA, USA). For activation, single-cell suspensions of tumor cells or spleen were resuspended in RPMI containing $100 \mathrm{ng} / \mathrm{ml}$ PMA (Sigma-Aldrich), $1 \mu \mathrm{g} / \mathrm{ml}$ ionomycin (Sigma-Aldrich), and brefeldin A (Sigma-Aldrich) for 4 hours at $37^{\circ} \mathrm{C}$. Intracellular staining was performed with FITC-conjugated anti-ROR- $\gamma$, anti-Foxp3, antiIL10 anti-IL-17 and anti-IFN- $\gamma$ (Biolegend). AnnexinV/7AAD (BioLegend, San Diego, CA, USA) staining was performed after B16F10 treatment with metformin (10-20 $\mathrm{mM})$. The fluorescence intensity of fluorochrome-labeled cells was measured by flow cytometry (FACSCanto II, BD Biosciences). FACSDiva software was used for calculating cell numbers, and data analysis was performed by FlowJo (FlowJo LLC, Ashland, OR, USA).

\section{Measurement of intracellular ROS}

Intracellular accumulation of ROS was monitored using 2,7-dichlorofluorescein diacetate (DCF-DA, Thermo Fisher Scientific, Waltham, MA, USA) or MitoSOX (Molecular Probes, OR, USA). B16F10 cells were seeded into 96-well plates and treated with different concentrations of metformin (Merck) for $24 \mathrm{~h}$. The medium was removed and cells were washed and incubated with DCF-DA $(5 \mu \mathrm{M})$ or MitoSOX $(5 \mu \mathrm{M})$ for $30 \mathrm{~min}$. Then, cells were washed and analyzed by flow cytometry.

\section{Seahorse extracellular flux}

Seahorse analysis experiments were performed as previously described [61]. In brief, B16F10 cells were plated and treated with $10 \mathrm{mM}$ of metformin 1 day prior to the seahorse experiment. Cells were allowed to equilibrate at $37^{\circ} \mathrm{C}$ for $30 \mathrm{~min}$ prior to starting the assay. Metformin $(50 \mu \mathrm{M})$, oligomycin (ATPase inhibitor, $0.5 \mu \mathrm{M})$, and FCCP $(0.2 \mu \mathrm{M})$ were injected and OCR ( $\mathrm{pmol} / \mathrm{min})$ was measured.

\section{Cytokine evaluation}

Cytokine concentrations were measured in the serum, spleen, and lung homogenates, then collected on the $15^{\text {th }}$ day after tumor cell inoculation. Lung homogenates were prepared by digesting lung tissues with $1 \mathrm{U} / \mathrm{mL}$ collagenase IV (Sigma-Aldrich) at $37^{\circ} \mathrm{C}$ 
for $30 \mathrm{~min}$. After centrifugation, the supernatants were stored at $-80^{\circ} \mathrm{C}$. IFN- $\gamma$, TNF- $\alpha$, IL-10, IL-17, IL-1 $\beta$, IL6 , and adiponectin were quantified by sandwich ELISA, following the manufacturer's instructions (R\&D Systems, Minneapolis, MN, USA).

\section{Statistical analysis}

Statistical analysis of experimental and control data was conducted by a Student $t$-test or two-way ANOVA with a Bonferroni post hoc test for multiple comparisons. In all studies, a value of $p<0.05$ was considered statistically significant.

\section{Abbreviations}

Type 2 diabetes (T2D); AMP-activated kinase (AMPK); interleukin (IL); receptor-interacting serine/ threonine-protein kinase 1 (RIPK1); oxygen consumption rate (OCR); lactate dehydrogenase (LDH).

\section{Author contributions}

FVP, SMK, EGR and NOSC conceived and designed the study. FVP, ACM, JSL, IAC, TTC, DCA, $\mathrm{ABL}, \mathrm{MIH}, \mathrm{MCR}, \mathrm{VAO}, \mathrm{CTO}$ and RMP did in vitro and in vivo experiments. FVP, EGR and NOSC analyzed and interpreted the data and wrote the manuscript.

\section{ACKNOWLEDGMENTS}

We thank M.D. Ph.D. Débora Castanheira, A.C. Camargo Cancer Center, São Paulo, Brazil, for providing the human tumor cell lines used in this study.

\section{CONFLICTS OF INTEREST}

The authors declare no conflicts of interest.

\section{FUNDING}

This work was supported by Coordenação de Aperfeiçoamento de Pessoal de Nível Superior (CAPES), Fundação de Amparo à Pesquisa do Estado de São Paulo (FAPESP grant numbers 2012/02270-2, 2013/10318-8 and 2015/21513-1 and 2017/05264-7), and Conselho Nacional de Desenvolvimento Científico e Tecnológico (CNPq). The funders had no role in study design, data collection and analysis, decision to publish, or preparation of the manuscript.

\section{REFERENCES}

1. Gray-Schopfer V, Wellbrock C, Marais R. Melanoma biology and new targeted therapy. Nature. 2007; 445:851-857.
2. Ravnan MC, Matalka MS. Vemurafenib in patients with BRAF V600E mutation-positive advanced melanoma. Clin Ther. 2012; 34:1474-1486.

3. Wolchok J. How recent advances in immunotherapy are changing the standard of care for patients with metastatic melanoma. Ann Oncol. 2012; 23:viii15-21.

4. Shaw RJ, Lamia KA, Vasquez D, Koo SH, Bardeesy N, Depinho RA, Montminy M, Cantley LC. The kinase LKB1 mediates glucose homeostasis in liver and therapeutic effects of metformin. Science. 2005; 310:1642-1646.

5. Franciosi M, Lucisano G, Lapice E, Strippoli GF, Pellegrini F, Nicolucci A. Metformin therapy and risk of cancer in patients with type 2 diabetes: systematic review. PLoS One. 2013; 8:e71583.

6. Morales DR, Morris AD. Metformin in cancer treatment and prevention. Annu Rev Med. 2015; 66:17-29.

7. Hadad S, Iwamoto T, Jordan L, Purdie C, Bray S, Baker L, Jellema G, Deharo S, Hardie DG, Pusztai L, MoulderThompson S, Dewar JA, Thompson AM. Evidence for biological effects of metformin in operable breast cancer: A pre-operative, window-of-opportunity, randomized trial. Breast Cancer Res Treat. 2011; 128:783-794.

8. Pollak MN. Investigating metformin for cancer prevention and treatment: The end of the beginning. Cancer Discov. 2012; 2:778-790.

9. Daugan M, Dufaÿ Wojcicki A, d'Hayer B, Boudy V. Metformin: An anti-diabetic drug to fight cancer. Pharmacol Res. 2016; 113:675-685.

10. DeWaal D, Nogueira V, Terry AR, Patra KC, Jeon SM, Guzman G, Au J, Long CP, Antoniewicz MR, Hay N. Hexokinase-2 depletion inhibits glycolysis and induces oxidative phosphorylation in hepatocellular carcinoma and sensitizes to metformin. Nat Commun. 2018; 9:446.

11. Singhal A, Jie L, Kumar P, Hong GS, Leow MK, Paleja B, Tsenova L, Kurepina N, Chen J, Zolezzi F, Kreiswirth $\mathrm{B}$, Poidinger $\mathrm{M}$, Chee $\mathrm{C}$, et al. Metformin as adjunct antituberculosis therapy. Sci Transl Med. 2014; 6:263ra159.

12. Yin Y, Choi SC, Xu Z, Perry DJ, Seay H, Croker BP, Sobel ES, Brusko TM, Morel L. Normalization of CD4+ $\mathrm{T}$ cell metabolism reverses lupus. Sci Transl Med. 2015; 7:274ra18.

13. Davidson A, Diamond B. Autoimmune diseases. N Engl J Med. 2001; 345:340-50.

14. Zhao D, Long XD, Lu TF, Wang T, Zhang WW, Liu YX, Cui XL, Dai HJ, Xue F, Xia Q. Metformin decreases IL-22 secretion to suppress tumor growth in an orthotopic mouse model of hepatocellular carcinoma. Int J Cancer. 2015; 136:2556-2565.

15. Kang KY, Kim YK, Yi H, Kim J, Jung HR, Kim IJ, Cho JH, Park SH, Kim HY, Ju JH. Metformin downregulates Th17 cells differentiation and attenuates murine autoimmune arthritis. Int Immunopharmacol. 2013; 16:85-92.

16. Pearce EL, Walsh MC, Cejas PJ, Harms GM, Shen H, Wang LS, Jones RG, Choi Y. Enhancing CD8 T-cell memory 
by modulating fatty acid metabolism. Nature. 2009; 460:103-107.

17. Michalek RD, Gerriets VA, Jacobs SR, Macintyre AN, MacIver NJ, Mason EF, Sullivan SA, Nichols AG, Rathmell JC. Cutting edge: Distinct glycolytic and lipid oxidative metabolic programs are essential for effector and regulatory CD4+ T cell subsets. J Immunol. 2011; 186:3299-3303.

18. Zarrouk M, Finlay DK, Foretz M, Viollet B, Cantrell DA. Adenosine-mono-phosphate-activated protein kinaseindependent effects of metformin in T cells. PLoS One. 2014; 9:e106710.

19. Ding L, Liang G, Yao Z, Zhang J, Liu R, Chen H, Zhou Y, Wu H, Yang B, He Q. Metformin prevents cancer metastasis by inhibiting M2-like polarization of tumor associated macrophages. Oncotarget. 2015; 6:36441-55. https://doi. org/10.18632/oncotarget.5541.

20. Vasamsetti SB, Karnewar S, Kanugula AK, Thatipalli AR, Kumar JM, Kotamraju S. Metformin inhibits monocyte-tomacrophage differentiation via AMPK-mediated inhibition of STAT3 activation: potential role in atherosclerosis. Diabetes. 2015; 64:2028-2041.

21. Park DW, Jiang S, Tadie JM, Stigler WS, Gao Y, Deshane J, Abraham E, Zmijewski JW. Activation of AMPK enhances neutrophil chemotaxis and bacterial killing. Mol Med. 2013; 19:387-398.

22. Gui DY, Sullivan LB, Luengo A, Hosios AM, Bush LN, Gitego N, Davidson SM, Freinkman E, Thomas CJ, Vander Heiden MG. Environment Dictates Dependence on Mitochondrial Complex I for NAD + and Aspartate Production and Determines Cancer Cell Sensitivity to Metformin. Cell Metab. 2016; 24:716-727.

23. Griss T, Vincent EE, Egnatchik R, Chen J, Ma EH, Faubert B, Viollet B, DeBerardinis RJ, Jones RG. Metformin Antagonizes Cancer Cell Proliferation by Suppressing Mitochondrial-Dependent Biosynthesis. PLoS Biol. 2015; 13:e1002309.

24. Ai Z, Lu Y, Qiu S, Fan Z. Overcoming cisplatin resistance of ovarian cancer cells by targeting HIF-1-regulated cancer metabolism. Cancer Lett. 2016; 373:36-44.

25. Scutti JA, Matsuo AL, Pereira FV, Massaoka MH, Figueiredo CR, Moreira DF, Belizário JE, Travassos LR. Role of SOCS-1 gene on melanoma cell growth and tumor development. Transl Oncol. 2011; 4:101-109.

26. Zhou X, Chen J, Yi G, Deng M, Liu H, Liang M, Shi B, Fu X, Chen Y, Chen L, He Z, Wang J, Liu J. Metformin suppresses hypoxia-induced stabilization of HIF-1 alpha through reprogramming of oxygen metabolism in hepatocellular carcinoma. Oncotarget. 2016; 7:873-84. https://doi.org/10.18632/oncotarget.6418.

27. Feoktistova M, Leverkus M. Programmed necrosis and necroptosis signalling. FEBS J. 2015; 282:19-31.

28. Poillet-Perez L, Despouy G, Delage-Mourroux R, BoyerGuittaut M. Interplay between ROS and autophagy in cancer cells, from tumor initiation to cancer therapy. Redox Biol. 2015 ; 4:184-192.

29. Son HJ, Lee J, Lee SY, Kim EK, Park MJ, Kim KW, Park SH, Cho ML. Metformin attenuates experimental autoimmune arthritis through reciprocal regulation of Th17/ Treg balance and osteoclastogenesis. Mediators Inflamm. 2014; 2014:973-986.

30. Lee CF, Lo YC, Cheng $\mathrm{CH}$, Furtmuller GJ, Oh B, Andrade-Oliveira V, Thomas AG, Bowman CE, Slusher BS, Wolfgang MJ, Brandacher G, Powell JD. Preventing allograft rejection by targeting immune metabolism. Cell Rep. 2015; 13:760-770.

31. Chae YK, Arya A, Malecek MK, Shin DS, Carneiro B, Chandra S, Kaplan J, Kalyan A, Altman JK, Platanias L, Giles F. Repurposing metformin for cancer treatment: current clinical studies. Oncotarget. 2016; 7:40767-80. https://doi.org/10.18632/oncotarget.8194.

32. Barreira da Silva R, Laird ME, Yatim N, Fiette L, Ingersoll MA, Albert ML. Dipeptidylpeptidase 4 inhibition enhances lymphocyte trafficking, improving both naturally occurring tumor immunity and immunotherapy. Nat Immunol. 2015; 16:850-858.

33. Chapman PB, Hauschild A, Robert C, Haanen JB, Ascierto P, Larkin J, Dummer R, Garbe C, Testori A, Maio M, Hogg D, Lorigan P, Lebbe C, et al. Improved survival with vemurafenib in melanoma with BRAF V600E mutation. N Engl J Med. 2011; 364:2507-2516.

34. Fedorenko IV, Gibney GT, Sondak VK, Smalley KS. Beyond BRAF: Where next for melanoma therapy? Br J Cancer. 2015; 112:217-226.

35. Dankort D, Curley DP, Cartlidge RA, Nelson B, Karnezis AN, Damsky WE, You MJ, DePinho RA, McMahon M, Bosenberg M. Braf (V600E) cooperates with Pten loss to induce metastatic melanoma. Nat Genet. 2009; 41:544-552.

36. Saisho Y. Metformin and inflammation: Its potential beyond glucose-lowering effect. Endocr Metab Immune Disord Drug Targets. 2015; 15:196-205.

37. Volarevic V, Misirkic M, Vucicevic L, Paunovic V, Simovic Markovic B, Stojanovic M, Milovanovic M, Jakovljevic V, Micic D, Arsenijevic N, Trajkovic V, Lukic ML. Metformin aggravates immune-mediated liver injury in mice. Arch Toxicol. 2015; 89:437-450.

38. Janjetovic K, Harhaji-Trajkovic L, Misirkic-Marjanovic M, Vucicevic L, Stevanovic D, Zogovic N, SumaracDumanovic M, Micic D, Trajkovic V. In vitro and in vivo anti-melanoma action of metformin. Eur J Pharmacol. 2011; 668:373-382.

39. Tomic T, Botton T, Cerezo M, Robert G, Luciano F, Puissant A, Gounon P, Allegra M, Bertolotto C, Bereder JM, TartareDeckert S, Bahadoran P, Auberger P, et al. Metformin inhibits melanoma development through autophagy and apoptosis mechanisms. Cell Death Dis. 2011; 2:e199.

40. Li P, Zhao M, Parris AB, Feng X, Yang X. p53 is required for metformin-induced growth inhibition, senescence and 
apoptosis in breast cancer cells. Biochem Biophys Res Commun. 2015; 464:1267-1274.

41. Yonekawa T, Gamez G, Kim J, Tan AC, Thorburn J, Gump J, Thorburn A, Morgan MJ. RIP1 negatively regulates basal autophagic flux through TFEB to control sensitivity to apoptosis. EMBO Rep. 2015; 16:700-708.

42. Babcook MA, Sramkoski RM, Fujioka H, Daneshgari F, Almasan A, Shukla S, Nanavaty RR, Gupta S. Comination simvastatin and metformin índices G-1 phase cell cycle arrest and Ripk1- and Ripk3-dependent necrosis in C4-2B osseous metastatic castration-resistant prostate cancer cells. Cell Death Dis. 2014; 5:e1536.

43. An D, Kewalramani G, Chan JK, Qi D, Ghosh S, Pulinilkunnil T, Abrahani A, Innis SM, Rodrigues B. Metformin influences cardiomyocyte cell death by pathways that are dependent and independent of caspase-3. Diabetologia. 2006; 49:2174-2184.

44. Liang G, Ding M, Lu H, Cao NA, Niu Y, Gao Y, Lu J. Metformin upregulates E-cadherin and inhibits B16F10 cell motility, invasion and migration. Oncol Lett. 2015; 10:1527-1532

45. Dowling RJ, Niraula S, Stambolic V, Goodwin PJ. Metformin in cancer: translational challenges. J Mol Endocrinol. 2012; 48:R31-43.

46. Eikawa S, Nishida M, Mizukami S, Yamazaki C, Nakayama E, Udono H. Immune-mediated antitumor effect by type 2 diabetes drug, metformin. Proc Natl Acad Sci USA. 2015; 112:1809-1814.

47. Gabrilovich DI, Ostrand-Rosenberg S, Bronte V. Coordinated regulation of myeloid cells by tumours. Nat Rev Immunol. 2012; 12:253-268.

48. Church SE, Jensen SM, Antony PA, Restifo NP, Fox BA. Tumor-specific CD4+ T cells maintain effector and memory tumor-specific CD8+ T cells. Eur J Immunol. 2014; 44:69-79.

49. Laidlaw BJ, Cui W, Amezquita RA, Gray SM, Guan T, Lu Y, Kobayashi Y, Flavell RA, Kleinstein SH, Craft J, Kaech SM. Production of IL-10 by CD4(+) regulatory $\mathrm{T}$ cells during the resolution of infection promotes the maturation of memory CD8(+) T cells. Nat Immunol. 2015; 16:871-879.

50. Dobrzanski MJ. Expanding roles for CD4 T cells and their subpopulations in tumor immunity and therapy. Front Oncol. 2013; 3:63.

51. Shklovskaya E, Terry AM, Guy TV, Buckley A, Bolton HA, Zhu E, Holst J, Fazekas de St Groth B. Tumour-specific CD4 T cells eradicate melanoma via indirect recognition of tumour-derived antigen. Immunol Cell Biol. 2016; 94:593-603.

52. Cuff S, Dolton G, Matthews RJ, Gallimore A. Antigen specificity determines the pro- or antitumoral nature of CD8+ T cells. J Immunol. 2010; 184:607-14.

53. Lee SY, Lee SH, Yang EJ, Kim EK, Kim JK, Shin DY, Cho ML. Metformin ameliorates inflammatory bowel disease by suppression of the STAT3 signaling pathway and regulation of the between Th17/Treg balance. PLoS One. 2015; 10:e0135858.

54. Stewart CA, Metheny H, Iida N, Smith L, Hanson M, Steinhagen F, Leighty RM, Roers A, Karp CL, Müller W, Trinchieri G. Interferon-dependent IL-10 production by Tregs limits tumor Th17 inflammation. J Clin Invest. 2013; 123:4859-4874.

55. Pace L, Tempez A, Arnold-Schrauf C, Lemaitre F, Bousso P, Fetler L, Sparwasser T, Amigorena S. Regulatory T cells increase the avidity of primary CD8 $+\mathrm{T}$ cell responses and promote memory. Science. 2012; 338:532-536.

56. Detaille D, Guigas B, Leverve X, Wiernsperger N, Devos P. Obligatory role of membrane events in the regulatory effect of metformin on the respiratory chain function. Biochem Pharmacol. 2002; 63:1259-72.

57. Miller RA, Birnbaum MJ. An energetic tale of AMPKindependent effects of metformin. J Clin Invest. 2010; 120:2267-70.

58. Logie L, Harthill J, Patel K, Bacon S, Hamilton DL, Macrae K, McDougall G, Wang HH, Xue L, Jiang H, Sakamoto K, Prescott AR, Rena G. Cellular responses to the metal-binding properties of metformin. Diabetes. 2012; 61:1423-33.

59. Cheng G, Zielonka J, Ouari O, Lopez M, McAllister D, Boyle K, Barrios CS, Weber JJ, Johnson BD, Hardy M, Dwinell MB, Kalyanaraman B. MitochondriaTargeted Analogues of Metformin Exhibit Enhanced Antiproliferative and Radiosensitizing Effects in Pancreatic Cancer Cells. Cancer Res. 2016; 76:3904-15.

60. Scharping NE, Menk AV, Moreci RS, Whetstone RD, Dadey RE, Watkins SC, Ferris RL, Delgoffe GM. The Tumor Microenvironment Represses T Cell Mitochondrial Biogenesis to Drive Intratumoral $\mathrm{T}$ Cell Metabolic Insufficiency and Dysfunction. Immunity. 2016; 45:701-03.

61. Chamoto K, Chowdhury PS, Kumar A, Sonomura K, Matsuda F, Fagarasan S, Honjo T. Mitochondrial activation chemicals synergize with surface receptor PD-1 blockade for T cell-dependent antitumor activity. Proc Natl Acad Sci USA. 2017; 114:E761-70.

62. Pathania D, Millard M, Neamati N. Opportunities in discovery and delivery of anticancer drugs targeting mitochondria and cancer cell metabolism. Adv Drug Deliv Rev. 2009; 61:1250-1275.

63. Li J, Kim SG, Blenis J. Rapamycin: One drug, many effects. Cell Metab. 2014; 19:373-379.

64. Zhao Y, Yang L, Zhou Z. Dipeptidyl peptidase-4 inhibitors: Multitarget drugs, not only antidiabetes drugs. J Diabetes. 2014; 6:21-29.

65. Yang Z, Lei Z, Li B, Zhou Y, Zhang GM, Feng ZH, Zhang B, Shen GX, Huang B. Rapamycin inhibits lung metastasis of B16 melanoma cells through down-regulating alpha-V integrin expression and up-regulating apoptosis signaling. Cancer Sci. 2010; 101:494-500. 
66. Pedicord VA, Cross JR, Montalvo-Ortiz W, Miller ML, Allison JP. Friends not foes: CTLA-4 blockade and mTOR inhibition cooperate during $\mathrm{CD} 8+\mathrm{T}$ cell priming to promote memory formation and metabolic readiness. J Immunol. 2015; 194:2089-2098.

67. Aso Y, Fukushima M, Sagara M, Jojima T, Iijima T, Suzuki K, Momobayashi A, Kasai K, Inukai T. Sitagliptin, a DPP-4 inhibitor, alters the subsets of circulating CD4+ T cells in patients with type 2 diabetes. Diabetes Res Clin Pract. 2015; 110:250-256.
68. Scharping NE, Menk AV, Whetstone RD, Zeng X, Delgoffe GM. Efficacy of PD-1 Blockade Is Potentiated by Metformin-Induced Reduction of Tumor Hypoxia. Cancer Immunol Res. 2017; 5:9-16.

69. Toricelli M, Melo FH, Peres GB, Silva DC, Jasiulionis MG. Timp1 interacts with beta-1 integrin and CD63 along melanoma genesis and confers anoikis resistance by activating PI3-K signaling pathway independently of Akt phosphorylation. Mol Cancer. 2013; 12:22. 